Article

\title{
Reaction Engineering of Direct Coal Liquefaction
}

\author{
Ken K. Robinson \\ Mega-Carbon Company, 5N553 Jens Jensen Lane, St. Charles, IL 60175, USA; \\ E-Mail: kkrob@earthlink.net; Tel.: +1-630-513-7454; Fax: +1-630-513-7454
}

Received: 14 October 2009 / Accepted: 23 October 2009 / Published: 29 October 2009

\begin{abstract}
Direct coal liquefaction has been studied and practiced since the 1930s. It was used in Germany during World War II to produce synthetic fuels when there was no oil allowed into the country. Since then, it has been studied in the United States and many different technologies have been investigated. Since the US is rich in coal resources, this is one way to be energy independent. Most of the development activity occurred in the 1980s and numerous technologies were studied, the most notable of these being H-Coal, Exxon Donor Solvent, Solvent Refined Coal, and Two Stage Liquefaction. The key elements of these technologies, particularly the reaction/reactor scheme, are discussed in this review.
\end{abstract}

Keywords: coal; liquefaction; reactors; kinetics; catalysis; deactivation; reaction engineering

\section{Introduction}

\subsection{A Brief History of Coal Liquefaction}

Interest in coal liquefaction has seen several high and low periods over the last 60 years. Direct coal liquefaction starts just prior to World War II by Germany, continues through the 1950s and 1960s with the research by the U.S. Bureau of Mines, and then hit an extensive pace following the Arab oil embargo of 1973. Since the early 1980s, interest has waned due to the decrease in crude oil prices, but the invasion of Kuwait by Iraq in 1990 caused the world to reevaluate their position and think about a national energy policy which will provide incentives to develop U.S. natural resources. The largest source of liquid hydrocarbons is crude oil and the United States has found and used up the cheap domestic crude that it once had. When demand exceeds supply, or a political or military action in one of the oil producing countries happens, the price of crude oil will increase. This stimulates alternative 
fuel options to produce liquid hydrocarbons from domestic energy resources such as coal. Coal liquefaction would be an attractive option for the United States due to the vast coal reserves.

In late 2008, Shenhua, China's top coal producer, conducted trial operations of a 1 million-ton/year (16,300 barrel/day) direct coal to liquid (CTL) production line producing quality diesel, naphtha and oil. As a key component of the national energy strategy, the Shenhua direct CTL project is based in coal-rich Inner Mongolia This trial run made China the only country in the world to have achieved key technologies for 1 million-ton-scale direct CTL production. The trial ended after 300 hours, but Shenhua made improvements so it could conduct a 1,000-hour trial the following month. However, in June 2009, China announced that the commercial plant had been put on hold due to concerns of economics and greenhouse gas emissions [1]. This CTL facility was reported to cost $\$ 1.46$ billion.

Before discussing direct coal liquefaction, it is important to briefly acknowledge the role of indirect coal liquefaction, consisting of coal gasification to synthesis gas (hydrogen and carbon monoxide) with subsequent conversion to liquid fuels via Fischer-Tropsch synthesis. Sasol runs an indirect coal liquefaction facility in South Africa and produces 160,000 barrels per day [2]. Robinson and Tatterson updated the economics of co-production of diesel fuel and electricity via integrated gasification combined cycle (IGCC) and identified a number of situations which produce a very attractive return on investment, particularly when the byproduct carbon dioxide is captured and sold for enhanced oil recovery [3,4]. Robinson and Tatterson [4] estimated an indirect coal liquefaction plant producing 9,000 barrels per day of diesel would cost $\$ 1.85$ billion or $\$ 205,000 /$ daily barrel. The China direct liquefaction plant is in the range of $\$ 90,000 /$ daily barrel for the capital investment, but it should be noted that it would probably be comparable to the indirect liquefaction capital costs if constructed in the U.S.

In a 1988 article, Lumpkin [5] said "the economics derived early in the 1980s established the price of transportation fuels from coal liquefaction at $\$ 80$ per barrel or higher. However there have been dramatic improvements in the technology since 1983 that have not been widely appreciated. Recent designs and cost estimates show that a $60 \%$ decrease in the cost of liquid fuels from coal relates to about \$35/barrel for crude oil”. When crude oil is priced at \$70-80/barrel (2009 dollars), direct coal liquefaction can achieve a reasonable return on investment, but product price guarantees need to be provided so that risk is reduced and investors are willing to provide money for the very high capital investment on a commercial plant Direct liquefaction involves the addition of hydrogen to coal in a solvent slurry at elevated temperature and pressure. The solvent provides a convenient transportation medium for the coal and enhances heat and mass transfer during chemical reaction. In many processes, the solvent shuttles hydrogen from the gas phase to the coal and is called a donor solvent. The elevated temperature cracks the coal molecules by thermally rupturing carbon-carbon linkages and increases the rate of reaction. High pressure keeps the solvent and products in the liquid phase, prevents coke build-up on the reactor walls and catalyst surface, and promotes hydrogenation by maintaining a high partial pressure of hydrogen. Catalysts are normally used to increase the rates of the desirable reactions which include cracking, hydrogenation, and removal of oxygen, nitrogen, and sulfur.

Coal consists of complex macromolecules without repeating monomer units that are built primarily of carbon and hydrogen but also consist of significant amounts of oxygen, nitrogen, and sulfur. The constituent units tend to be mostly substituted aromatics or hydroaromatics and the degree of condensation increases as the coal matures. Coal has a hydrogen-to-carbon ratio which is significantly 
less that petroleum; converting coal into liquids requires either the addition of substantial amounts of hydrogen or the removal of excess carbon.

The coal time line for the 20th century [6] helps to trace the major events that have occurred in our recent history. Direct coal liquefaction technology developed from work on hydrogenating coal tar by Bergius in Germany in the 1920s [7]. A major improvement was the development of sulfur-resistant hydrogenation catalyst by Pier in BASF's laboratories in Ludwigshaven, Germany in 1924. The first German brown coal was hydrogenated in 1929. In the 1930s, several plants were built in Germany, and one in Billingham, England. The original Bergius plants consisted of liquid-phase hydrogenation of coal/recycle slurry followed by vapor-phase hydrogenation of middle oils. Both hydrogenation reactors operated with catalyst and pressures of 5,000-10,000 psig.

German capacity increased to the point that during World War II, eight additional plants were built in Germany. In 1943, the installed capacity was over 100,000 BSD in 15 plants processing about 50,000 tons of dry coal per day. The US Bureau of Mines tested the German technology after World War II in a 200 barrel per day pilot plant. All of these efforts were technically successful, but could not compete economically with inexpensive petroleum from the Middle East in the early 1950s.

Second generation technology came along in the late 1970s and early 1980s. The U.S. pilot plants to develop these processes included:

1. SRC-II (solvent refined coal) in Tacoma, Washington and Wilsonville, Alabama

2. EDS (Exxon Donor Solvent) in Baytown, Texas

3. H-Coal in Catlettsburg, Kentucky.

Both the SRC-II and EDS process depended on a donor solvent for hydrogen during the liquefaction and used the minerals in the coal for a catalyst. EDS did use a catalytic stage to hydrotreat part of the recycle solvent in a second reactor but no catalyst was used in the coal liquefaction unit. The H-Coal process was developed by Hydrocarbon Research Inc. (HRI) and was derived from their $\mathrm{H}$-Oil process for petroleum resid upgrading. The basis of the process was a novel catalytic reactor in which the catalyst was ebullated in the liquid phase, similar to the more familiar gas-phase fluidized bed processes used in the petroleum industry. The advantage of this type reactor is that the reactor contents are well mixed helping to alleviate the excessive heat release associated with coal liquefaction plus the ability to add and withdraw catalyst from the reactor while it is operating so that the catalyst activity is maintained at a relatively high and constant level. The U.S. Department of Energy (DOE) and a consortium of industrial sponsors built a 250 ton per day pilot plant at Catlettsburg, Kentucky which ran from June 1980 to January 1983. The plant was a technical success and confirmed yields by smaller scale equipment and a wide variety of mechanical equipment was tested including ebbulation pumps, pressure letdown and block valves, and hydroclones to concentrate the solids-containing product. Although the process was not economic, two developments promised further cost reductions. The first was a new catalyst developed by Amoco researchers with a unique bimodal pore size distribution resulting in less catalyst deactivation, and most importantly higher liquid yields. The second improvement came from Chevron Research, a two stage liquefaction scheme which lowered hydrogen consumption by tailoring reaction conditions in each stage to favor the reactions of coal dissolution, hydrogenation of the donor solvent. thermal/catalytic conversion of the high molecular weight species (residuum) and removal of sulfur, nitrogen, and oxygen. Finally, a six ton per day pilot plant at Wilsonville, AL sponsored by Southern Company, Electric Power Research Institute, the US 
Department of Energy, and Amoco was operated in the 1980s. It was a two stage Solvent Refined Coal process and achieved some major success with the incorporation of a catalytic reactor to hydrogenate the donor solvent and critical solvent deashing, developed by Kerr-McGee. Unlike the earlier SRC process development, it was operated to make a much lighter product slate of distillate and/or syncrude with two basic modes, integrated two stage liquefaction (ITSL) and double integrated two stage liquefaction (DITSL).

\subsection{Process Overview of Coal Liquefaction}

Direct coal liquefaction refers to the direct reaction of coal with hydrogen to form liquids. The hydrogen reacts with oxygen, sulfur, and nitrogen in coal to remove them as water, hydrogen sulfide, and ammonia. The hydrogen is also required to hydrogenate the donor solvent which in turn transfers hydrogen to the dissolved coal thereby substantially increasing the $\mathrm{H} / \mathrm{C}$ ratio of the coal as it is liquefied. One of the key differences between coal and petroleum is the much lower $\mathrm{H} / \mathrm{C}$ atomic ratio of coal ( 0.7 vs 1.5 for petroleum, see Table 3 ). Consequently the conversion of coal to petroleum-like products requires direct hydrogen addition and this adds considerable expense to the product.

The ideal technology for direct coal liquefaction for gasoline production would:

- produce only $\mathrm{C}_{5}-400^{\circ} \mathrm{F}$ products which contain no nitrogen, oxygen, or sulfur hydrocarbon gases

- produce no light since these gases consume large amounts of hydrogen

- produce aromatic liquid for octane requirements to reduce hydrogen consumption

- remove oxygen from coal by carbon rejection to carbon oxides rather than hydrogenation

None of the current coal liquefaction processes accomplish this. Second-generation liquefaction processes now under development are descendants of the classic Bergius technology. Most involve, more or less, catalyzed interactions between molecular hydrogen and coal-oil slurries of elevated pressure and temperature. The new processes $\left(2,500 \mathrm{psi}, 800-850{ }^{\circ} \mathrm{F}\right)$ are different: (1) they operate at less severe conditions; (2) they place a great deal of emphasis on $\mathrm{H}$ transfer from the slurry oil to the coal; (3) careful attention is paid to producing process-derived solvent to recycle to the front end of the process for slurrying the coal. The following table lists these "second-generation" processes and how they compare:

Table 1. Coal liquefaction process summary.

\begin{tabular}{clcc}
\hline Name & \multicolumn{1}{c}{ Reactor Type } & Demonstration Unit & Capacity, TPD \\
\hline H-Coal & ebullated bed w/recycle & Catlettsburg, KY & 200 \\
Exxon Donor & plug-flow dissolver + catalytic solvent & Baytown, TX & 250 \\
Solvent & hydrotreater & Tacoma, WA and & 50 \\
SRC I \& II & plug-flow preheater/dissolver & Wilsonville, AL & 6 \\
Two stage & plug-flow preheater/dissolver \& & Wilsonville, AL & 6 \\
liquefaction & ebullated bed hydrotreater & & 6 \\
\hline
\end{tabular}




\section{Coals and Conversion Chemistry}

The reactions characterizing coal dissolution are not clear but there is some agreement that coal forms intermediate products consisting of "preasphaltenes", also called asphaltols, and asphaltenes which can convert to oil. Unreacted coal, oil precursors and oil are defined by whether they are soluble in particular organic solvents, of which benzene is the most commonly used. Sometimes toluene is substituted for benzene since it is much safer to use. One of many possible reaction paths is shown below.

Figure 1. Coal liquefaction chemistry.

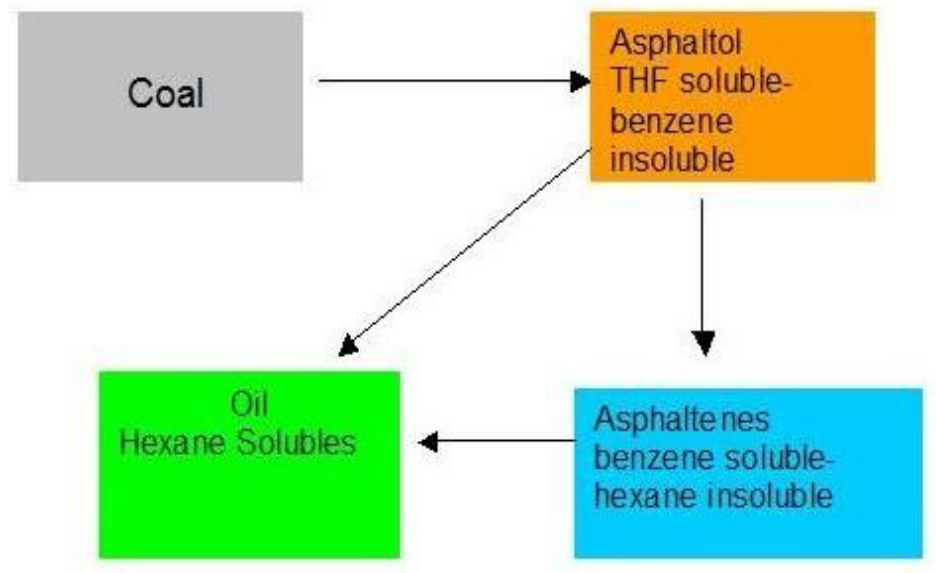

Three solvents are used to characterize coal liquids, tetrahydrofuran (THF which has replaced pyridine), benzene, and hexane. Asphaltols are defined as THF soluble-benzene insoluble, asphaltenes being benzene soluble-hexane insoluble, and finally oils defined as hexane soluble. In the reaction path shown above, coal converts first to asphaltols, which then can convert to either asphaltenes or oils, and then asphaltenes converting to oils. This is completely a solvent solubility classification.

\subsection{Coals: Classification, Nomenclature and Structure}

The following is an excerpt from Peter Given's [8] course on coal science at Pennsylvania State University. His excellent and vibrant description of coal cannot really be improved upon by the author so it has been left relatively untouched.

"Coal can reasonably be described as an organic rock. As such, it is, like other rocks, a heterogeneous assembly of more specifically definable components, and the plant debris from which it originated has undergone a progressive series of alterations as a result of geological or geochemical processes.

Whenever materials are used, it is desirable to be able to relate properties as determined by simple measurements in the laboratory to behavior in an industrial process; if such a relationship can be established, one has a basis for selecting the best material for a given process, or for modifying operating conditions to utilize most effectively the material available. Therefore, as with any other material, it is important to be able to classify coals and coal components in some manner helpful to utilization, on the basis of standard laboratory tests. 
There are at least seven characteristics of coals that are or may be relevant to their behavior in conversion processes: rank, geological history, mineral content, trace element distribution, petrographic composition, chemical structural parameters and pore structure. The coal "series" allows coals to be classified by the carbon content as:

peat $---\rightarrow$ lignite $---\rightarrow$ sub-bituminous $---\rightarrow$ bituminous $---\rightarrow$ anthracite

When we study coals, what we see in nature is an apparently continuous series of alterations from living plant material through dead material, peat, lignite, sub-bituminous and bituminous coals and anthracite to graphite. The process of alteration from the peat stage onward is called metamorphism, and the term "rank" is used in the scientific literature to signify the degree of alteration or metamorphism. Rank is of such importance in defining the properties of coals that we must discuss it at some length."

For simplicity, Table 2 makes it appear that coals are distributed along a single development line. In fact any plot of a coal property against a measure of the degree of metamorphism is a band, rather than a line. That is, there have evidently been a number of related pathways by which plant debris has been progressively altered and passed along the coal series. Nevertheless, the degree of alteration is of overriding importance in determining what set of properties a coal will have. If you are going to use a coal, its rank is always the first thing that you want to know about it.

The A.S.T.M. system used for commercial purposes in the U.S., and the International Systems used in Europe, depend upon volatile matter to classify the higher rank coals, and calorific values for the lower, which is fair enough as far as it goes. These properties are used to classify coals into about ten categories, as shown in Table 3.

Table 2. ASTM classification of coal.

\begin{tabular}{ccccc}
\hline Class & Group & $\begin{array}{c}\text { Fixed } \\
\text { Carbon, maf }\end{array}$ & $\begin{array}{c}\text { Volatile } \\
\text { Matter, maf }\end{array}$ & $\begin{array}{c}\text { Heating } \\
\text { Value, BTU/lb }\end{array}$ \\
\hline Anthracite & metaanthracite & $>98$ & $<2$ & \\
& anthracite & $92-98$ & $2-8$ & \\
& semianthracite & $86-92$ & $8-14$ & \\
\hline Bituminous & low-volatile & $78-86$ & $14-22$ & $>14,000$ \\
& med volatile & $69-78$ & $22-31$ & \\
& high volatile A & $<69$ & $>31$ & $10,500-11,500$ \\
& high volatile B & & & $9,500-10,500$ \\
& high volatile C & & & $6,300-8,300$ \\
Subbituminous & subbituminous A & & & $<6,300$ \\
& subbituminous B & & & \\
& subbituminous C & & & \\
\hline Lignitic & lignite A & & & \\
& lignite B & & & \\
\end{tabular}

People sometimes speak of a coal as being, for example, of high volatile A bituminous rank, as if the statement uniquely defined the rank. It would be more accurate and less liable to lead to misconceptions if one spoke of a coal as being in a certain rank range. Each rank category in fact 
covers a portion of the total rank range, and the high volatile A category in particular contains coals of considerably different degrees of metamorphism (e.g., the carbon content may be between about $80 \%$ and $87 \%$, and the oxygen content between $11 \%$ and $4 \%$ ).

A further characteristic of coals that may be of practical importance is their geological history. Coals are known in almost every state of this nation, though in some states the deposits are too small to be of much commercial significance. There were two principal coal-forming periods, the coals of the central and western states being much younger than those of the eastern and southeastern states. This means that coals on different sides of the continent were derived from plants of quite different type, since a great deal of evolution occurred in the 150 million years between the Carboniferous and the Cretaceous. Moreover, for any one geological age, coals were deposited in a number of distinct basins in different parts of the country, and experienced distinctly different geological histories.

Table 3. Values of coal properties in different rank ranges.

\begin{tabular}{|l|c|c|c|c|c|c|c|c|}
\cline { 3 - 8 } \multicolumn{2}{c|}{} & \multicolumn{2}{c|}{$\begin{array}{c}\text { High Vol } \\
\text { Bituminous }\end{array}$} & \multicolumn{2}{c|}{ Bituminous } & \multicolumn{2}{c|}{} \\
\hline & Lignite & Subbit. & B & A & $\begin{array}{c}\text { Med } \\
\text { Volatile }\end{array}$ & $\begin{array}{c}\text { Low } \\
\text { Volatile }\end{array}$ & Anthracite & Petroleum \\
\hline$\%$ C (ash free) & $65-72$ & $72-76$ & $78-80$ & $80-87$ & 89 & 90 & 93 & $83-87$ \\
\hline$\%$ H & 4.5 & 5 & 5.5 & 5.5 & 4.5 & 3.5 & 2.5 & $10-14$ \\
\hline$\%$ O & 30 & 18 & 10 & $10-4$ & $3-4$ & 3 & 2 & $0.1-1.5$ \\
\hline H/C, atomic & 0.77 & 0.8 & 0.82 & 0.8 & 0.6 & 0.46 & 0.32 & 1.7 \\
\hline$\%$ O as OH & $15-10$ & $12-10$ & $?$ & $7-3$ & $1-2$ & $0-1$ & 0 & \\
\hline $\begin{array}{l}\text { Aromatic C } \\
\text { atoms \% of } \\
\text { total C }\end{array}$ & 50 & 65 & $?$ & 75 & $80-85$ & $85-90$ & $90-95$ & \\
\hline $\begin{array}{l}\text { Av. no. } \\
\text { benzene } \\
\text { rings/layer }\end{array}$ & $1-2$ & & $2-3$ & $2-3$ & $2-3$ & 5 & $>25$ & \\
\hline $\begin{array}{l}\text { Vol. } \\
\text { Matter, \% }\end{array}$ & $40-50$ & $35-50$ & & $31-40$ & $31-20$ & $20-10$ & $<10$ & \\
\hline $\begin{array}{l}\text { Reflectance, } \\
\%, \text { Vitrinite }\end{array}$ & $0.2-0.3$ & $0.3-0.4$ & 0.6 & $0.6-1.0$ & 1.4 & 1.8 & 4 & \\
\hline $\begin{array}{l}\text { Calorific } \\
\text { value, maf } \\
\text { free, BTU/lb. }\end{array}$ & 7000 & 10000 & 13500 & 14500 & 15000 & 15800 & 15200 & \\
\hline
\end{tabular}

\subsection{Sulfur in Coal}

When coal is analyzed carefully for both major and trace constituents, almost every element will be found. About the only exceptions are the highly radioactive elements that are made artificially and some of the noble gases. Of the roughly 80 elements found in coal, the one besides carbon having the most significant effect on coal use is sulfur. When coal or coal liquids are burned, the sulfur oxides formed cause air pollution if allowed to escape into the environment. The sulfur in coal has caused the spending of millions of dollars on equipment and processes to capture the sulfur oxides or to reduce the sulfur content of coal before it is burned. Sulfur occurs in coal in three forms: 
1. organic sulfur, which is a part of the molecular composition of the coal itself;

2. pyritic sulfur, which occurs in the mineral pyrite and some related minerals; and

3. sulfate sulfur, which is mostly iron sulfates.

In most coals, sulfate sulfur is a small fraction of the total sulfur content. In low-rank coals, organic sulfur may contribute half or more of the total sulfur, but in most bituminous coals, the majority of the sulfur is pyritic sulfur.

\subsection{Inorganic Constituents in Coal}

Coal contains a rich variety of inorganic constituents. Mineral grains in coal can sometimes be seen with the unaided eye and are easily seen through a microscope. When coal is burned it leaves behind the inconsumable inorganic residue known as ash. The ash is the product of reactions or transformations of the inorganic components of coal caused by the high temperatures of the combustion process.

Several sources contribute inorganic material to coal. The first is the coal-forming plants themselves. Most plants contain at least small amounts of inorganic substances; that is why burning logs in a fireplace always leave some ash. However, some plants concentrate significant quantities of inorganic material. For example, the scouring rushes concentrate enough silica in their cell walls to give them a gritty texture that pioneers found useful for cleaning cooking utensils or scouring floors. The scouring rushes are examples of the last surviving genus (the horsetails) of a class of plants that were prevalent in the coal swamps of the Carboniferous period. Some of the inorganic components of coal were in the original plant material.

During the diagenetic stage of coal formation, as the organic sediments were accumulating in the swamps, ample opportunities occurred for inorganic debris to be deposited by either water currents or wind. This debris would settle into the organic sediments and become part of the coal that eventually formed. Clay particles are deposited into coal in this way. Minerals transported into the coal-forming environment by wind or water are called detrital minerals.

Although all types of inorganic material in coal are important, either because of their deleterious effects in coal processing or because of their adverse environmental impact and potential health hazards, the relative abundance of different inorganic constituents makes it appropriate to distinguish between major and minor constituents.

1. The major constituents are clay minerals (aluminosilicates), which occur mostly as illite, kaolinite, montmorillonite, and mixed illite-montmorillonite and commonly make up as much as 50\% of the total mineral matter contents;

2. carbonate minerals, principally calcite $\left(\mathrm{CaCO}_{3}\right)$, siderite $\left(\mathrm{FeCO}_{3}\right)$, dolomite $\left(\mathrm{FeCO}_{3}-\mathrm{MgCO}_{3}\right)$, and ankerite $\left(2 \mathrm{CaCO}_{3}-\mathrm{MgCO}_{3}-\mathrm{FeCO}_{3}\right)$, but frequently also present as variously composed mixed carbonates of $\mathrm{Ca}, \mathrm{Mg}, \mathrm{Mn}$, and $\mathrm{Fe}$;

3. sulfides, which are mainly present as pyrite and marcasite (i.e., dimorphs of FeSx, which only differ in crystal habit), but which have also been reported in the form of galena $(\mathrm{PbS})$ and sphalerite $(\mathrm{ZnS})$; and

4. silica, which is ubiquitous as quartz and usually accounts for up to $20 \%$ of all mineral matter. 


\subsection{Coal Liquefaction Catalysis}

Catalysis plays an important role in coal liquefaction and has led to important technical advances and improved economics for producing liquid synfuels. A catalyst is defined as a substance which accelerates or changes the course of a chemical reaction without being consumed itself. The influence of the catalyst on liquefaction rate is actually not very noticeable since many of the liquefaction reactions take place in the absence of the catalyst. It is generally believed that some of the minerals (i.e., pyrite) present in coal provide a catalytic function, particularly for bituminous coals. However, once the coal has been initially liquefied, a catalyst will help to hydrocrack the coal liquid constituents, remove sulfur, nitrogen, and oxygen as hydrogen sulfide, ammonia, and water and rehydrogenate the hydrogen donor solvent.

The way in which one makes catalyst improvements is not straight-forward. A heterogeneous catalyst is generally preferred in coal liquefaction since separation of products from the catalyst is simplified. However, mixing of a soluble catalyst with the coal slurry provides intimate contacting at the molecular scale.

\subsection{The Porous Structure of Catalysts}

Coal liquefaction catalysts are highly porous materials, and typically show some aspects of pore diffusion control. Molecular transport in pores depends on the size of the pore. We can categorize pores as follows:

1. Bulk flow-Large pores

2. Ordinary diffusion-Large pores

3. Knudsen diffusion-Small pores

The relative balance of the surface reaction rate to the diffusion rate establishes the concentration profile in the catalyst particle. If diffusion is rapid or surface reactions slow, then the concentration of reactant will not drop very sharply as we travel down the pore. On the other hand, a slow diffusion rate or fast surface reaction will produce a sharp concentration gradient in the catalyst particle; then the reaction on the external surface is much higher than in the particle interior.

The table below lists the properties of some catalysts developed by Amoco and W.R. Grace under an EPRI contract [9] The "bimodal" pore size distribution is characterized by the inclusion of macropores greater than $1,000 \AA$ in diameter.

This inclusion of these larger transport pores is important for activity maintenance and a higher catalyst effectiveness factor. The mean diameter of the smaller pores (APD) should be around $120 \AA$ to accommodate the large coal-derived molecules. 
Table 4. Catalyst inspection data for coal liquefaction catalysts.

\begin{tabular}{|l|c|c|c|c|c|c|c|}
\hline & \multicolumn{2}{|c|}{$\begin{array}{c}\text { Composition, } \\
\mathrm{wt} \%\end{array}$} & $\begin{array}{c}\text { Average Pore } \\
\text { Diameter }\end{array}$ & $\begin{array}{c}\text { Surface } \\
\text { Area }\end{array}$ & PV & PV of $10^{3}-10^{5} \AA$ & ABD \\
\hline Catalyst & $\mathrm{CoO}$ & $\mathrm{MoO}_{3}$ & $\AA$ & $\mathrm{m}^{2} / \mathrm{g}$ & $\mathrm{cc} / \mathrm{g}$ & $\%$ of total & $\mathrm{g} / \mathrm{cc}$ \\
\hline Bimodal Catalysts \\
\hline $\begin{array}{l}\text { Cyanamid HDS- } \\
\text { 1442A }\end{array}$ & 3.1 & 13.2 & 58 & 323 & 0.64 & 26.1 & 0.567 \\
\hline CoMo-120 APD & 3.2 & 16.2 & 122 & 154 & 0.6 & 11.1 & 0.665 \\
\hline Mo-120 APD & - & 14.9 & 123 & 167 & 0.65 & 9.6 & 0.656 \\
\hline Unimodal Catalysts & \multicolumn{7}{|l|}{} \\
\hline CoMo-120 APD & 3 & 15.5 & 115 & 162 & 0.62 & 4.7 & 0.733 \\
\hline CoMo-120 APD & 0.5 & 16 & 121 & 160 & 0.64 & 3.2 & 0.723 \\
\hline
\end{tabular}

\subsection{Selection of the Appropriate Rate Equations for Modeling}

The rate equations for catalytic hydroliquefaction can take many forms, depending on which step or steps are slowest and rate controlling. The rate equations for these various situations are listed below:

\subsubsection{External mass transport limitations}

Hydrogen transfer controls at bubble interface

When the transport of hydrogen gas from bubbles to the bulk liquid is the slowest step the rate equation is:

$$
{ }_{-} r_{A}=\frac{1}{V_{i}} \frac{d N_{A}}{d t}=\frac{p_{A}}{\frac{1}{k_{A_{g} a_{i}}}+\frac{H_{A}}{k_{A_{l} a_{i}}}}
$$

$$
\begin{aligned}
& \text { where } a_{i}=\frac{S}{V_{i}}=\frac{\text { interfacial surface area }}{\text { volume of liquid }} \\
& k_{A_{g}}=\text { gas film mass transfer coefficient } \\
& k_{A_{l}}=\text { liquid film mass transfer coefficient } \\
& \left(k_{A_{l}}\right)_{i}\left(\frac{\mu_{l}}{\rho_{l} D_{i l}}\right)^{\frac{2}{3}}=0.31\left(\frac{\Delta \rho_{l} g \mu_{l}}{\rho_{l}^{2}}\right)^{\frac{1}{3}} \\
& a_{i}=\frac{6 \varepsilon g}{d_{B}} \\
& \varepsilon g=\text { fractional gas holdup } \\
& d_{B}=\text { bubble diameter }(.3-.6 \mathrm{~mm})
\end{aligned}
$$


The interfacial area of the gas bubbles, $\mathrm{a}_{\mathrm{i}}$, is a critical parameter in this case. If the gas bubbles are large, we can increase reaction rate by better dispersion of the gas into the liquid phase, to produce smaller bubbles (increasing interfacial area, $\mathrm{a}_{\mathrm{i}}$ ). Obviously there is a practical limit, because an unstable foam will eventually develop as bubble size is decreased.

Film resistance effects at catalyst surface

When the catalyst is functioning well and the catalytic rate fast, the external mass transfer may be the rate limiting step. As soon as the reactants reach the external catalyst surface, they react. This causes the film around the catalyst particle to limit transport of fresh reactant to the surface and, in turn, to control the overall reaction rate.

$$
-r_{A}^{\prime}=\frac{1}{W} \frac{d N_{A}}{d t}=\frac{p_{A}}{\frac{1}{k_{A_{f} i}{ }^{a}}+\frac{1}{k}}
$$

$$
\text { where } \begin{aligned}
a_{i} & =\frac{A_{c}}{W}=\frac{\text { external catalyst surface area }}{\text { weight of catalyst }} \\
k_{A_{f}} & =\text { mass transfer coefficient at catalyst film } \\
k & =\text { catalytic rate constant (based on weight) }
\end{aligned}
$$

$$
\begin{gathered}
\boldsymbol{a}_{\boldsymbol{i}}=\frac{\mathbf{6} \boldsymbol{m}}{\boldsymbol{d}_{\boldsymbol{p}} \mathbf{p}^{\boldsymbol{s}}} \\
m=\text { catalyst concentration, } g / \ell \\
\left(\frac{\boldsymbol{k}_{\boldsymbol{A}} \boldsymbol{d}_{\boldsymbol{p}}}{\boldsymbol{D}_{\boldsymbol{i} \boldsymbol{m}}}\right)^{2}=\mathbf{4 . 0}+\mathbf{1 . 2 1} N_{\boldsymbol{P e}}^{\frac{2}{\mathbf{3}}} \\
N_{P e} \text { Peclet number }=d_{p} \frac{U}{D}
\end{gathered}
$$

\subsubsection{Catalytic reaction controls}

If the reaction at the catalyst surface is the slowest step in the catalytic process, then one of the following equations may apply for the reaction rate. 


$$
A+B \rightarrow R+S
$$

$$
\begin{aligned}
& \text { Rate Limiting Step Rate Equation } \\
& A+s \rightleftharpoons A s \quad-r=\frac{k\left(C_{A}-C_{R} / K C_{S}\right.}{1+K_{R B} C_{R} / C_{S}+K_{B} C_{B}+K_{R} C_{R}} \\
& B+s \rightleftharpoons B s \quad-r=\frac{k\left(C_{A}-C_{R} / K C_{A}\right.}{1+K_{A} C_{A}+K_{R A} C_{R} / C_{A}+K_{R C_{R}}} \\
& A s+B s \rightleftharpoons R s+s \quad-r=\frac{k\left(C_{A} C_{B}-C_{R} / K\right.}{1+K_{A} C_{A}+K_{B} C_{B}+K_{R} C_{R}} \\
& R s \rightleftharpoons R+s \quad-r=\frac{k\left(C_{a} C_{S}-C_{R} / K\right)}{1+K_{A} C_{A}+K_{B} C_{B}+K_{A B} C_{A} C_{B}} \\
& \text { where }-r=\frac{1}{w} \frac{d N_{A}}{d t} \\
& -r=\frac{\text { moles reacted }}{\text { hour-wt catalyst }}
\end{aligned}
$$

\subsubsection{Pore diffusion limitations}

The effectiveness factor discussed earlier is the ratio of the diffusion affected rate to the non-diffusion rate or effectiveness factor, $\eta=r^{\prime} / r$. Thus to account for pore diffusion limitations, the effectiveness factor is included in the rate equation as a multiplier of the catalytic rate constant. If we begin to include other transport effects, the effectiveness factor will still be associated with the catalytic rate constant. Referring back to the case where film resistance effects were present at the catalyst surface we would use, the effectiveness factor as follows:

No Pore Diffusion Effects

Pore Diffusion Effects

$$
\begin{aligned}
& \text { first order kinetics }-\boldsymbol{r}_{\boldsymbol{A}}=\boldsymbol{k} \boldsymbol{C}_{\boldsymbol{A}} \\
& \text { mass transport effects }-r_{A}=\frac{p_{A}}{\frac{1}{k_{f} a_{i}}+\frac{1}{k}} \\
& -r_{A}=\frac{p_{a}}{\frac{1}{k a_{i}}+\frac{1}{k \eta}} \\
& \begin{array}{l}
\boldsymbol{\eta}=\frac{\tanh \varphi}{\varphi} \text { where } \boldsymbol{\varphi}=\boldsymbol{L} \sqrt{\frac{k}{D}} \\
\boldsymbol{\eta}=\frac{1}{\varphi} \quad \text { for } \varphi>5
\end{array}
\end{aligned}
$$$$
{ }^{-r_{A}}=k \eta C_{A}
$$

(strong pore diffusion effects) 


\section{Approach for Coal Liquefaction Reactor Design}

Fulton [10] has pointed out that reactor design for a heterogeneous catalyst involves two major phases. First, the researcher collects experimental reaction-rate data that are free of heat- and masstransfer effects (i.e., intrinsic kinetic data). Second, the design engineer combines the intrinsic rate with the specific-heat and mass-transfer effects appropriate to the plant-sized reactor to be designed.

In the second phase, the design of a commercial liquefaction reactor, the design engineer must take into account the variety of heat-transfer, mass-transfer and reaction phenomena that occur.

In the first phase, the generation of intrinsic reaction-rate data, the researcher must:

1. Build and operate the reactor to minimize axial and radial transport (intrareactor) effects; e.g., isothermal operation is highly desirable. We should define time "zero" (no long heat-up) in batch reactor test by using a charging bomb, to inject the reactants into the reactor after heat-up.

2. Operate the reactor at a mixing rate large enough to eliminate heat- and mass-transfer gradients between the catalyst particle and the bulk fluid (particle-fluid or interphase).

3. Use catalyst particles small enough to eliminate the influence of intraparticle heat and mass gradients.

With these precautions taken, the observed reaction rate will most likely be the intrinsic rate-i.e., the true catalytic reaction rate. As a result, the researcher needs methods for determining whether transport effects are influencing the laboratory data. The "limiting criteria" allow the researcher to calculate or experimentally determine whether these transport effects are important. They, in turn, guide the researcher to reactor operating conditions that will provide data free from transport effects.

Key rate parameters are modified by the influence of different transport regimes. For example, if diffusion is strongly influencing the overall reaction rate, the energy of activation determined experimentally will be about one-half the intrinsic reaction energy of activation. As a result, the Arrhenius correlation for reaction rate would be grossly in error.

Table 5. Observed versus actual behavior for catalytic reactions.

$$
-\mathrm{r}_{\mathrm{A}}=\mathrm{kC}_{\mathrm{A}}{ }^{\mathrm{n}}=\mathrm{A} \exp [-\Delta \mathrm{E} / \mathrm{RT}] \mathrm{C}_{\mathrm{A}}{ }^{\mathrm{n}}
$$

\begin{tabular}{|c|c|c|c|c|}
\hline Domain & $\begin{array}{c}\text { Activation } \\
\text { Energy }\end{array}$ & Order & $\begin{array}{c}\text { Pellet } \\
\text { Size }\end{array}$ & $\begin{array}{c}\text { Fluid } \\
\text { Velocity }\end{array}$ \\
\hline $\begin{array}{c}\text { Chemical } \\
\text { Reaction }\end{array}$ & $\Delta \mathrm{E}$ & $\mathrm{n}$ & Independent & Independent \\
\hline $\begin{array}{c}\text { Diffusion } \\
\text { reaction }\end{array}$ & $\Delta \mathrm{E} / 2$ & $(\mathrm{n}+1) / 2$ & $1 /$ Length & Independent \\
\hline $\begin{array}{c}\text { Bulk mass } \\
\text { transfer }\end{array}$ & $5 \mathrm{kcal} / \mathrm{mole}$ & $1 \mathrm{st}$ & $(1 / \text { Length })^{3 / 2}$ & Velocity $^{1 / 2}$ \\
\hline
\end{tabular}

The kinetic parameters (reaction order and activation energy) are altered as the data-collection basis moves from the chemical-reaction, and through the intrapellet and interphase, controlling domains. The influence of pellet size and fluid velocity on rate becomes greater as bulk mass transfer becomes more important. Displayed above is the characteristic behavior of kinetic parameters appropriate to each controlling regime. 


\subsection{Catalyst Deactivation}

In general, catalyst deactivation occurs by three mechanisms, (1) sintering of the supported metals on the surface, (2) poisoning by compounds which strongly and irreversibly adsorb on to the active sites and (3) fouling, where coke forms on the surface of the catalyst which limits access to the active metals and also reduces the diameter of the pores, eventually leading to pore mouth plugging.

Coking, sintering and ash deposition all contribute to catalyst deactivation in coal liquefaction, the degree depending upon the coal type and processing conditions. Used catalyst characterizations are described below for work in pilot plant studies at Amoco [9]. Studies on spent catalysts from the Wilsonville pilot plant [11] give insight on catalyst deactivation. It should be noted that the catalyst was in the second of two stages and not directly exposed to the initial coal liquefaction environment, in the first stage dissolver.

The catalyst used in all three runs was Shell $324 \mathrm{M}$ with $12.4 \mathrm{wt} \% \mathrm{Mo}, 2.8$ wt \% Ni and 2.7 wt \% P on an alumina support. Catalyst samples were withdrawn periodically throughout each run with only minor $(5 \%)$ catalyst additions to the hydrotreater. All samples were Soxhlet extracted with tetrahydrofuran and dried under vacuum at $100{ }^{\circ} \mathrm{C}$ prior to characterization and activity testing. A portion of each extracted sample was regenerated by slowly heating to $500{ }^{\circ} \mathrm{C}$ in a muffle furnace in air. Regeneration removed the carbonaceous deposits but did not affect the contaminant metals. Studies of both aged and regenerated catalysts enable separation of the effects of both carbonaceous deposits and contaminant metals. The types of processing options practiced at Wilsonville include:

Run 242 ITSL integrated two stage liquefaction (interstage deashing)

Run 246 DITSL doubly integrated two stage liquefaction (two recycle streams)

Run 247 RITSL reconfigured integrated two stage liquefaction (post 2nd stage deashing)

Characterization of the catalysts included studies of the buildup of carbonaceous deposits and contaminant metals as well as changes in physical properties. Quantitative carbon analyses show that the carbon buildup is very rapid in samples from all three runs. Catalysts from Wilsonville run 246 attain a carbon content of $7.3 \mathrm{wt} \%$ during DITSL processing which then increases to $9.0 \mathrm{wt} \%$ during ITSL processing. Catalysts from Wilsonville run 242 (ITSL processing) attain a carbon content of $9.3 \mathrm{wt} \%$ after about $133 \mathrm{lb}$ resid/lb catalyst which then remains constant throughout the remainder of the run. Samples from Wilsonville run 247 with RITSL processing attain the highest carbon content of $10.8 \mathrm{wt} \%$, which decreases twice during the run to values of $\sim 10 \mathrm{wt} \%$ after $100 \mathrm{lb}$ resid/lb catalyst and to 8.9 wt $\%$ after $300 \mathrm{lb}$ resid/lb catalyst. These two decreases in carbon are correlated with temperature increases in the reactor from 680 to $700{ }^{\circ} \mathrm{F}$ and from 700 to $710{ }^{\circ} \mathrm{F}$, respectively. The carbon contents in catalyst samples from these three runs are correlated with the quantity of heavy resid and unconverted coal in the hydrotreater feed. DITSL processing has the lightest feed whereas RITSL processing has the heaviest feed because deashing, (which normally removes some unconverted coal and heavy resid) was performed after the 2nd stage catalytic hydrotreater.

Many contaminant metals are deposited on the catalyst during coal liquefaction processing. However, iron and titanium are the most abundant. The lowest Ti content was observed on the run 246 catalysts which processed subbituminous coal. This result is in agreement with previous studies on catalysts from single stage direct coal liquefaction processes which showed that Wyodak coal resulted in lower Ti buildup than Illinois No. 6 coal. Since the Wyodak coal and Illinois No. 6 coal have similar 
Ti contents, the difference must be due to the presence of $\mathrm{Ti}$ phases in the subbituminous coal that are less reactive with the catalyst than those of the bituminous coal.

\subsection{Catalyst Design for Coal Liquefaction}

The design of a coal liquefaction catalyst is an extremely challenging problem. Due to the large heat release associated with coal liquefaction, the reactor contents should be mixed sufficiently so that temperature gradients are maintained at some acceptable level. This usually means, we use a commercial reactor (typified by the ebullated H-Coal type) with a recycle pump to circulate the exit steam back to the reactor inlet.

This sets the physical constraint on the catalyst, its geometry, density, and abrasion resistance. The catalyst particles are suspended in the upwardly flowing coal liquid. The particles have two key forces acting on them, the buoyant force of the coal liquid they displace and the frictional drag from the flowing liquid. Typically, extrudates about $1 / 8$ " in diameter are used in the H-Coal reactor. In contrast, the H-Oil reactor (for petroleum resid upgrading) can use the smaller 1/16" particles with little trouble since the liquid is less dense and provides less buoyant force for a given volumetric displacement. The minimum fluidization velocity [12] can be estimated as:

$$
\begin{aligned}
U_{m f} & =\frac{d_{p}{ }^{2}\left(\rho_{s}-\rho_{g}\right) g}{1650 \mu} \quad R e_{p}<20 \\
U_{m f} & =\left[\frac{d_{p}\left(\rho_{s}-\rho_{g}\right) g}{24.5 \rho_{g}}\right] 1 / 2 \quad R e_{p}>1000 \\
\text { where } d_{p} & =\text { particle diameter } \\
\rho_{S} & =\text { density of solid } \\
\rho_{g} & =\text { density of fluid phase } \\
\mu & =\text { viscosity of fluid } \\
g & =\text { acceleration of gravity, } 980 \mathrm{~cm} / \mathrm{sec}^{2} \\
\operatorname{Re}_{p} & =\text { particle Reynolds number, } \mathrm{d}^{\mathrm{u}} \mathrm{\rho}_{\mathrm{g}} / \mu \\
U_{m f} & =\text { minimum fluidization velocity }
\end{aligned}
$$

The second aspect is activity of the catalyst. This implies a highly porous support which provide plenty of active surface. We select the particular combination of catalytic metals based on which of the reactions we need to promote.

Levy and Cusumano [13] have noted, "Before a material is tested for catalytic coal liquefaction, its chances of survival in the liquefaction environment should be examined. The presence of $\mathrm{H}_{2} \mathrm{~S}$ poses the most severe problem. A large number of compounds that may ordinarily be considered promising candidates sulfide in this environment. It is therefore fruitless to spend considerable effort in the testing of these materials. Compounds that are expected to resist sulfidation include a number of oxides, nitrides, borides and silicides."

Finally we must consider catalyst stability or how well it survives the coal liquefaction environment. Pore structure, specifically a bimodal pore size distribution of macro (>1,000 $\AA$ diam) and meso (20 $\AA<\mathrm{d}<600 \AA$ ) pore is the key to acceptable activity maintenance. Coking of the catalyst causes a rapid initial decline in the activity. Then a more gradual deactivation occurs due to sintering and 
additional coking. The inclusion of macropore volume is accomplished in the catalyst forming step such as extrusion. The drawback of the macropores is that the catalyst is "softer" and can sometimes grind up when it is in the reactor being ebullated. Thus, there is a practical upper limit (25\% of total) of macropore volume that one aims to stay under.

In summary, design of a coal liquefaction catalyst represents a balance of properties. The type of reactor, coal type, reaction severity, and desired product quality will all enter into the design of the catalyst. As a base point, the properties of the Amocat ${ }^{\mathrm{TM}}$ family of catalysts is given below for use in catalytic hydroliquefaction of coal. They have enjoyed considerable success in Wilsonville, AL and the H-Coal pilot plant at Catlettsburg, KY.

Table 6. Catalysts used in pilot plant studies.

\begin{tabular}{|c|c|c|c|}
\hline Catalyst Name & Amocat $^{\mathrm{TM}} \mathbf{1 A}$ & Amocat $^{\mathrm{TM}}$ 1B & Amocat $^{\text {TM }} 1 \mathrm{C}$ \\
\hline \multicolumn{4}{|l|}{ Composition, wt \% } \\
\hline $\mathrm{MoO}_{3}$ & $16 \pm 0.9$ & $16 \pm 0.9$ & $16 \pm 0.9$ \\
\hline $\mathrm{CoO}$ & $3 \pm 0.4$ & & \\
\hline $\mathrm{NiO}$ & & & $3 \pm 0.4$ \\
\hline $\mathrm{CaO}$ & $\leq 0.1$ & $\leq 0.1$ & $\leq 0.1$ \\
\hline $\mathrm{SO}_{4}$ & $\leq 0.5$ & $\leq 0.5$ & $\leq 0.5$ \\
\hline $\mathrm{Al}_{2} \mathrm{O}_{3}$ & balance & balance & balance \\
\hline \multicolumn{4}{|l|}{ Surface Properties } \\
\hline BET Surface Area, $\mathrm{M}^{2} / \mathrm{g}$ & $170 \mathrm{~min}$ & & $\longrightarrow$ \\
\hline $\begin{array}{l}\text { Pore Volume, cc/gm } \\
(<1200 \AA \text { diam })\end{array}$ & $0.65 \mathrm{~min}$ & & \\
\hline Total pore volume, cc/gm & 70.82 & & $\longrightarrow$ \\
\hline Pore size distribution & bimodal & & $\longrightarrow$ \\
\hline $\begin{array}{l}\text { Total pore volume in } \\
\text { macropores (>1200 } \\
\text { diam), } \%\end{array}$ & $18 \pm 5$ & & \\
\hline $\begin{array}{l}\text { Pore Volume in micropores } \\
<40 \AA \text { A diam) }\end{array}$ & $<2$ & & \\
\hline \multicolumn{4}{|l|}{ Physical Properties } \\
\hline Shape & extrudate & & $\longrightarrow$ \\
\hline Size, in. & $1 / 16-1 / 10$ & & $\longrightarrow$ \\
\hline $\begin{array}{l}\text { Bulk density, compacted, } \\
\mathrm{lb} / \mathrm{ft}^{2}\end{array}$ & $37 \pm 3$ & & \\
\hline $\begin{array}{l}\text { Fines content, } 16 \text { mesh, } \\
\text { wt } \%\end{array}$ & $<1$ & & \\
\hline \multicolumn{4}{|l|}{ Suggested Use } \\
\hline Liquefaction & $\mathrm{X}$ & $\mathrm{X}$ & $\mathrm{X}$ \\
\hline Desulfurization & $\mathrm{X}$ & & \\
\hline Denitrogenation & & & $X$ \\
\hline Aromatic saturation & $X$ & & $\mathrm{X}$ \\
\hline
\end{tabular}


Liquefaction catalyst performance should almost always be measured in a continuous flow reactor. Catalyst life is a critical factor in coal liquefaction and fresh catalyst activity is only important to establish where the catalyst starts out. Coke deposits rapidly on the catalyst the first few days that it is on-stream and then a more gradual increase occurs. Catalyst is usually evaluated for at least 10 days and preferably around 30. A Continuous Stirred Tank Reactor (CSTR) high pressure autoclave is preferred and these are described by Autoclave Engineers [14].

\section{Commercial/Pilot Plant Reactor Design and Scale-Up}

The design of larger liquefaction reactors provides a significant challenge since heat release is substantial and the flow regime deviates from the ideals of plug flow and perfect mixing. We will examine the commercial reactors in increasing order of complexity.

\subsection{Exxon Donor Solvent (EDS) Reactor}

The liquefaction reactor used in the EDS process is a network of tubes with no catalyst inside. Coal slurry and hydrogen gas are introduced in the inlet with a nominal residence time of 30-45 minutes. The key issue is establishing the coal slurry residence time since gas bubbles occupy some fraction of the reactor volume (gas holdup, $\varepsilon_{\mathrm{g}}$, liquid holdup, $\varepsilon_{1}=1$ ). Although hydrogen is consumed along the length of the reactor, light gases are also formed, so it is not easy to predict the gas and liquid holdup volumes.

The "axial dispersion" model, a one-parameter model, is a good approximation for the EDS reactor. Its flow regime has a small deviation from plug flow conditions. The reactor coils are immersed in a heat transfer fluid so that the temperature rise along the length of the reactor can be controlled by transferring heat out. The material and energy balances are the following:

\section{Enery Balance}

$$
\begin{aligned}
\boldsymbol{\rho} \boldsymbol{u} \boldsymbol{C}_{\boldsymbol{p}} \frac{\boldsymbol{d} \boldsymbol{T}}{\boldsymbol{d z}} & =\boldsymbol{r}_{\boldsymbol{A}}-\Delta \boldsymbol{H}_{\boldsymbol{R}}+\boldsymbol{U}\left(\frac{\boldsymbol{P}}{\boldsymbol{A}}\right)\left(\boldsymbol{T}_{\boldsymbol{S}}-\boldsymbol{T}\right) \boldsymbol{T}=\boldsymbol{T}_{\mathbf{0}} @ \boldsymbol{Z}=\mathbf{0} \\
\text { where } C_{A} & =\text { concentration of species } A \\
T & =\text { temperature } \\
Z & =\text { axial position in reactor, } 1 / L \text { (dimensionless) } \\
D & =\text { diffusivity } \\
u & =\text { superficial velocity, } Q / A \\
L & =\text { reactor length } \\
(D / u L) & =\text { dispersion } \text { number } \\
\rho & =\text { fluid density } \\
C_{p} & =\text { fluid heat capacity } \\
r_{A} & =\text { reaction rate of } A, \text { moles } / \text { hr }-f^{3}{ }^{3} \text { reactor } \\
U & =\text { heat transfer coefficient } \\
P & =\text { perimeter of reactor } \\
A & =\text { cross }- \text { sectional area of reactor } \\
T_{S} & =\text { coolant temperature } \\
\tau & =\text { space time, hr. }
\end{aligned}
$$




$$
\begin{array}{rr}
\left(\frac{D}{u L}\right) \frac{d^{2} C_{A}}{d Z^{2}}+\frac{d C_{A}}{d Z}+\tau r_{A}=0 & C_{A}=C_{A_{0}} @ Z=0 \\
C_{A}=C_{A_{F}} @ Z=1
\end{array}
$$

The above equation is used for every reaction of interest and the set of equations are solved simultaneously with a numerical differential equation solver. The estimation of the Dispersion coefficient can be accomplished by the following equation by Shah [15].

$$
\begin{aligned}
\frac{\mathbf{1}}{\boldsymbol{P}_{\boldsymbol{e}}}=\left(\frac{\boldsymbol{D}}{\boldsymbol{u L}}\right)=\left(\frac{\boldsymbol{\mu}_{\boldsymbol{l}}^{\mathbf{g}}}{\boldsymbol{\rho l}^{\mathbf{3}}}\right)^{-} & \left(\frac{\mathbf{. 0 3}}{\sqrt{\overline{\boldsymbol{D}}^{\mathbf{3}} \mathbf{g}}}\right)^{\mathbf{L}}\left[\mathbf{1}\left[\mathbf{0 . 0 3 7}+\mathbf{. 1 8 8}\left(\frac{\boldsymbol{U}_{\mathbf{0 g}}}{\sqrt{\mathbf{g} \overline{\boldsymbol{D}}}}\right)^{. \mathbf{7 2}}\right]\right. \\
\text { where } \mu_{l} & =\text { viscosity of liquid } \\
g & =\text { gravitaional acceleration } \\
\rho \boldsymbol{l} & =\text { density of liquid } \\
\delta & =\text { surface tension } \\
U_{0 L} & =\text { superficial velocity of liquid } \\
U_{0 g} & =\text { superficial velocity of gas } \\
\bar{D} & =\text { diameter of column } \\
L & =\text { length of column } \\
P_{l} & =\text { Peclet number }
\end{aligned}
$$

Liquid and gas holdup are also estimated from formulas in Shah's book.

$$
\begin{gathered}
\text { Gas Holdup, } \varepsilon_{g} \\
\frac{\boldsymbol{\varepsilon}_{\boldsymbol{g}}}{\mathbf{1 - \boldsymbol { \varepsilon } _ { \boldsymbol { g } } ^ { 4 }}}=\boldsymbol{C}_{\mathbf{1}} N_{\boldsymbol{B o}}^{\mathbf{1 / 8}} N_{\boldsymbol{G a}}^{\mathbf{1 / 1 2}} \boldsymbol{F}_{\boldsymbol{r g}}
\end{gathered}
$$

where $\varepsilon_{g}=$ volume fraction gas

$$
\begin{aligned}
N_{B o} & =g \bar{D}^{2} \rho_{l} / \sigma, \text { (Bond number) } \\
N_{G a} & =g \bar{D}^{3} \rho_{l}^{2} / \mu_{l}^{2}, \text { (Galileo number) } \\
F_{r g} & =u_{g} \sqrt{g \bar{D}}, \text { (Froude number) }
\end{aligned}
$$


Liquid Holdup, $\varepsilon_{a}$

$$
\varepsilon_{l}=\left(1-\varepsilon_{g}\right)\left(1-\frac{C_{S}}{\rho_{S}}\right)
$$

$$
\text { where } \begin{aligned}
\varepsilon_{l} & =\text { volume fraction liquid } \\
\varepsilon_{g} & =\text { volume fraction gas } \\
C_{S} & =\text { catalyst concentration, wt/volume slurry } \\
\rho_{S} & =\text { density of solid phase }
\end{aligned}
$$

Effective liquid volume, $V_{R}=\varepsilon_{7} V_{\text {tntal }}$

This sets the superficial velocity $\left(\mathrm{u}_{1}=\mathrm{Q} / \varepsilon_{1} \mathrm{~A}\right)$ and, in turn the residence time $\left(\tau=\mathrm{L} / \mathrm{u}_{1}\right)$ of the liquid in the reactor.

\subsection{H-Coal Reactor}

The H-Coal reactor is rather unique and called an ebullated bed catalytic reactor. A recycle pump, located either internally or externally, circulates the reactor fluids down through a central downcomer and then upward through a distributor plate and into the ebullated catalyst bed. The reactor is usually insulated well and operated adiabatically.

Figure 2. H-Coal reactor.

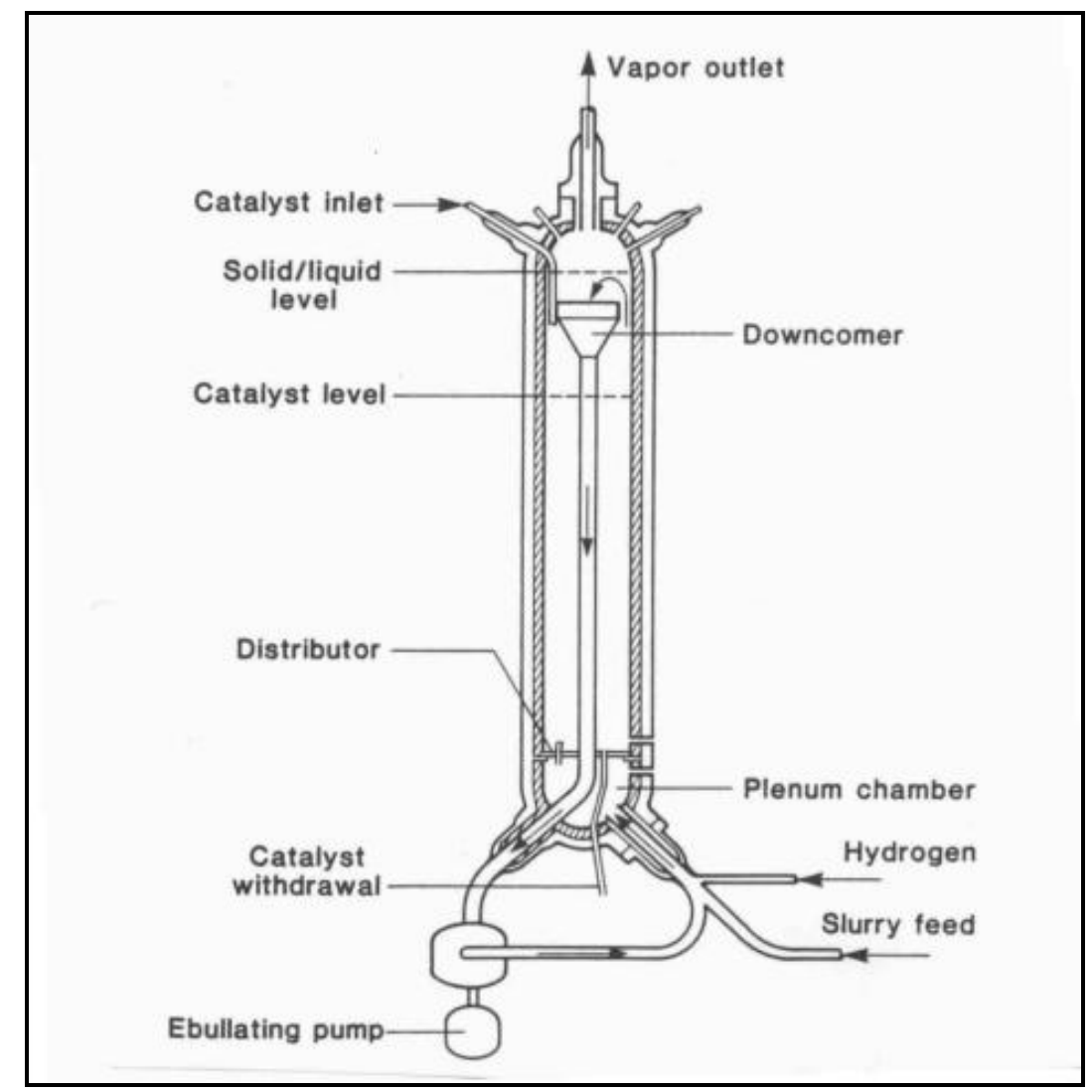


Frequently the reactor mixing pattern is defined as backmixed, but this is not strictly true. A better description of the flow pattern is plug flow with recycle or dispersed plug flow with recycle. For plug flow with recycle, we use a model as shown below in Figure 3.

Figure 3. Recycle reactor.

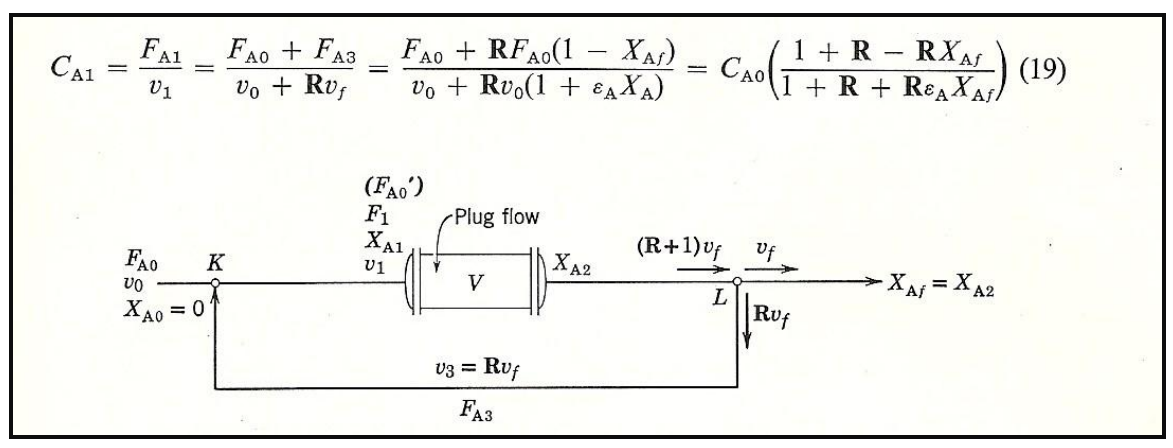

Then one can develop the following two equations, one for a first order reaction and the other for second order kinetics in a plug flow reactor with recycle. The equations for the axial dispersion model are modified appropriately to account for recycle conditions.

Design Equations for Plug Flow with Recycle

First Order Reaction

$$
k \tau=(1+R) \ln \left[\frac{C_{A o}+R C_{A f}}{(R+1) C_{A f}}\right]
$$

Second Order Reaction

$$
k \tau=\frac{R+1}{C_{A o}}\left[\frac{C_{A o}\left(C_{A o}-C_{A f}\right)}{C_{A f}\left(C_{A o}+R C_{A f}\right)}\right]
$$

where $k=$ rate constant, $1 / \mathrm{sec}$

$\tau=$ space time, sec

$R=$ recycle ratio

$C_{A o}=$ feed concentration, moles $/ \mathrm{ft}^{3}$

$C_{A f}=$ final concentration, moles $/ f t^{3}$

The schematic above in Figure 3, shows the key elements of recycling a portion of the exit stream with the feed stream and how that affects the feed concentration(s). The recycle increases the superficial velocity, $\mathrm{u}$, and changes the feed concentration due to dilution with the product stream.

Although the H-Coal reactor is loaded with catalyst, not all of the reactions are catalyzed; some are thermal reactions, like thermal cracking, which depend on liquid holdup and not on how much catalyst is present. Thus the material balance equations need to be divided into two categories, one set for the non-catalytic thermal reactions and another set for the catalytic reactions. A convenient parameter to use is the thermal/catalytic ratio, T/C, which is the ratio of liquid holdup to catalyst volume. In a commercial ebullated bed, this ratio is close to 1.0 under ebullation conditions. Consequently the material balance equations for the catalytic reactions with no recycle is: 
Dispersion Model with No Recycle Catalytic Reaction Only

Material Balance

$$
\begin{aligned}
& {\left[\frac{D}{u L}\right] \frac{d^{2} C_{A}}{d z^{2}}-\frac{d C_{A}}{d z}+\frac{\tau r_{A}^{\prime} \rho_{B}}{(T / C)}=0 \quad C_{A}=C_{A_{0}} @ z=0} \\
& C_{\boldsymbol{A}}=C_{\boldsymbol{A}_{\boldsymbol{f}}} @ z=1
\end{aligned}
$$

where $T / C=$ thermal volume to catalytic volume

$C_{A}=$ concentration of species $A$

$z=$ axial position in reactor, $l / L$ (dimensionless $)$

$D=$ diffusivity

$u=$ superficial velocity, $Q / A$

$L=$ reactor length

$(D / u L)=$ dispersion number

$r_{A}^{\prime}=$ catalytic reaction rate of $A$, moles $/ h r-w t$ of catalyst

$\tau=$ space time, $L / u$

$\rho_{B}=$ bulk density of catalyst, $\frac{w t}{\text { volume }}$

$r_{A}=$ thermal reaction rate, moles/hr-volume reactor

$R=$ recycle ratio, $\frac{\text { volume recycled }}{\text { volume leaving }}$

The final set of equations for the H-Coal reactor can now be written to account for the recycle situation, and thermal reactions in concert with catalytic reactions.

Dispersion Model with Recycle

Catalytic and Thermal Reaction

\section{Material Balance}

$$
\begin{aligned}
& {\left[\frac{D}{u L}\right] \frac{d^{2} C_{A}}{d z^{2}}-\frac{d C_{A}}{d z}+\tau\left[r_{A}+\frac{r_{A} \rho_{B}}{(T / C)}\right]=0} \\
& C_{A}=C_{A_{0}} \frac{1+R-R\left[1-C_{f} / C_{A_{o}}\right]}{1+R} @ z=0 \\
& C_{A}=C_{A_{f}} @ z=1
\end{aligned}
$$

Energy Balance

$$
\rho u C_{P} \frac{d T}{d z}=\left(r_{A}-\Delta H_{R}\right)+\left(r_{A}^{\left.-\Delta H_{R}\right)} \quad T=T_{0} @ z=0\right.
$$

The model for the H-Coal reactor introduces two complications beyond the axial dispersion model. First the boundary conditions are modified to account for the recycle and second the catalyst in the reactor means that both thermal and catalytic reactions are occurring simultaneously. The equations are solved numerically with a differential equation solver. This allows the reactor size to be 
determined by integrating along dimensionless distance $\mathrm{z}$ until concentration of $\mathrm{A}, \mathrm{C}_{\mathrm{A}}$, equals the desired final concentration, $\mathrm{C}_{\mathrm{Af}}$.

Table 7. Liquefaction reactor guide.

\begin{tabular}{|c|c|c|c|}
\hline Reactor Type & Positive & Negative & Best Application \\
\hline \multicolumn{4}{|l|}{ Research and Development Scale } \\
\hline \multirow[b]{2}{*}{ Micro-batch } & - Inexpensive & - Moderate mixing & - Coal screening \\
\hline & - Small feed charge & $\begin{array}{l}\text { - Difficult product work- } \\
\text { up }\end{array}$ & $\begin{array}{l}\text { - Catalyst } \\
\text { screening }\end{array}$ \\
\hline \multirow[b]{2}{*}{ Stirred Batch autoclave } & - Good mixing/contacting & - More expensive & \\
\hline & - Product work-up no problem & - Hard to set time zero & \\
\hline \multirow{3}{*}{$\begin{array}{l}\text { Mahoney-Robinson continuous stirred } \\
\text { autoclave (spinning basket) }\end{array}$} & $\begin{array}{l}\text { - Excellent mixing, bubble } \\
\text { dispersion }\end{array}$ & - Smaller catalyst charge & - Catalyst aging \\
\hline & & - Expensive & - Coal comparison \\
\hline & & $\begin{array}{l}\text { - Heavy feeds may not } \\
\text { work well }\end{array}$ & - Kinetic studies \\
\hline \multirow{2}{*}{$\begin{array}{l}\text { Robinson-Mahoney continuous stirred } \\
\text { autoclave (stationary basket) }\end{array}$} & - Handles heavy viscous feeds & - Expensive & - Kinetic studies \\
\hline & - Holds most catalyst & & $\begin{array}{l}\text { - Catalyst life } \\
\text { studies }\end{array}$ \\
\hline \multirow[t]{2}{*}{ Trickle Bed } & - Simple to operate & $\begin{array}{l}\text { - Isothermal operation } \\
\text { difficult }\end{array}$ & - Catalyst aging \\
\hline & - Simple to design & $\begin{array}{l}\text { - Flow maldistribution } \\
\text { common }\end{array}$ & $\begin{array}{l}\text { - Coal liquid } \\
\text { upgrading }\end{array}$ \\
\hline \multicolumn{4}{|l|}{ Demonstration/Commercial Scale } \\
\hline \multirow[t]{2}{*}{ H-Coal } & - Extensive operating history. & - Tricky to operate & $\begin{array}{c}\text { - Commercial } \\
\text { operations }\end{array}$ \\
\hline & $\begin{array}{l}\text { - Handles exothermic reactions } \\
\text { well }\end{array}$ & & \\
\hline \multirow[t]{2}{*}{ Exxon EDS } & - Simpler operation & $\begin{array}{l}\text { - Heat release hard to } \\
\text { control }\end{array}$ & $\begin{array}{l}\text { - Commercial } \\
\text { operation }\end{array}$ \\
\hline & & $\begin{array}{l}\text { - Hydrogen starvation } \\
\text { possible }\end{array}$ & \\
\hline \multirow[t]{3}{*}{ Two-stage } & - Better control of reactions & $\begin{array}{l}\text { - More complex to } \\
\text { operate }\end{array}$ & $\begin{array}{l}\text { - Commercial } \\
\text { operations }\end{array}$ \\
\hline & - Improved yield of distillates & & \\
\hline & - Builds on H-Coal technology & & \\
\hline
\end{tabular}

\subsection{Pilot Plant Processes}

The following section contains "short-form" process descriptions for some of the leading technologies in direct coal liquefaction. There are no direct coal liquefaction processes currently in commercial use. China has one which has been fully designed and is under construction. Not only are the production costs expensive, the disposal of waste streams is also a big issue. For example, the residue cannot be burned in a conventional boiler due to its high ash content ( 23\%) and sulfur level. Options have included gasification to generate hydrogen but current thinking leans toward fluid bed combustion for process heat. Natural gas and process-derived fuel gas appear to be the better raw materials for generating hydrogen for use in the process. 
The four processes described in this section include:

1. H-Coal Process

2. Exxon Donor Solvent (EDS)

3. Solvent Refined Coal (SRC I \& II)

4. Two Stage Liquefaction

\subsubsection{Process: H-Coal}

Description: Direct catalytic hydroliquefaction process developed by HRI, Inc using a novel ebullated bed reactor [16]. Typical reactor conditions are 3,000 psi, $850{ }^{\circ} \mathrm{F}$, and $75 \mathrm{lb} \mathrm{coal} / \mathrm{hr}-\mathrm{ft}^{3}$ for fuel oil mode or $30 \mathrm{lb}$ coal $/ \mathrm{hr}^{-\mathrm{ft}^{3}}$ for syncrude mode.

- Background:

- Patented process (US 3,321,393) developed by HRI, Inc.

- Extension of H-Oil process for residuum hydrotreatment.

- Bench scale and process development unit (PDU) operated at the Trenton, NJ laboratories.

- H-Coal Pilot plant (200 TPD syncrude or 600 TPD fuel oil mode) built and operated at Catlettsburg, KY.

- Operator: Ashland Synthetic Fuels, Inc.

- Cost: \$320 MM

- Participants: US Department of Energy(DOE), Kentucky Department of Energy, Ashland Oil, Electric Power Research Institute (EPRI), Mobil Oil, Standard Oil (Ind), Conoco Coal Development, Ruhrkohle AG

- Process Schematic:

Figure 4. H-Coal process.

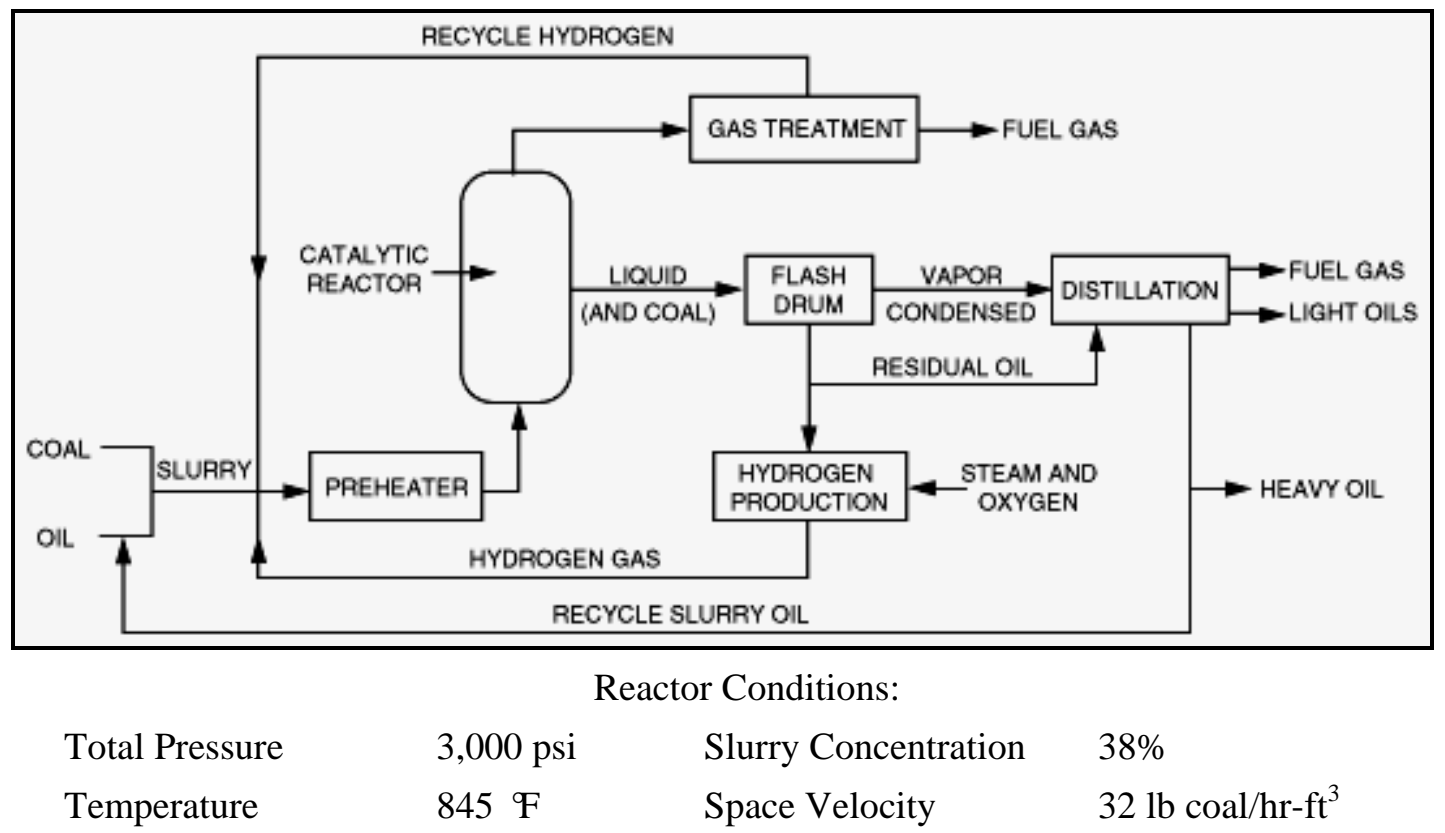


Table 8. Process Yields for H-Coal Process.

\begin{tabular}{lccc}
\hline Process Yields (lb/lb mf coal) & \multicolumn{2}{c}{$\begin{array}{c}\text { Illinois } \\
\text { Bituminous }\end{array}$} & $\begin{array}{c}\text { Wyoming } \\
\text { Subbituminous }\end{array}$ \\
\hline Product & Syncrude & Fuel Oil & Syncrude \\
$\mathrm{H}_{2}$ & $(5.3)$ & $(3.4)$ & $(6.2)$ \\
$\mathrm{H}_{2} \mathrm{O}, \mathrm{CO}, \mathrm{CO}_{2}$ & 7.1 & 6.5 & 20.0 \\
$\mathrm{H}_{2} \mathrm{~S}, \mathrm{NH}_{3}$ & 3.6 & 2.2 & 1.6 \\
$\mathrm{C}_{1}-\mathrm{C}_{3}$ & 11.2 & 6.8 & 12.3 \\
$\mathrm{Naphtha}\left(\mathrm{C} 4-204^{\circ} \mathrm{C}\right)$ & 18.7 & 13.4 & 25.8 \\
Fuel Oil $\left(204-524{ }^{\circ} \mathrm{C}\right)$ & 29.1 & 20.8 & 18.6 \\
Bottoms $\left(524{ }^{\circ} \mathrm{C}+\right)$ & 35.6 & 53.7 & 27.9 \\
TOTAL & 100 & 100 & 100 \\
\hline
\end{tabular}

Table 9. Liquefaction catalysts for H-Coal process.

\begin{tabular}{lccc}
\hline Name & Amocat $1 \mathrm{~A}^{\mathrm{TM}}$ & Amocat $1 \mathrm{~B}^{\mathrm{TM}}$ & Cyanamid HDS 1442A \\
\hline Composition & $3 \% \mathrm{CoO} / 10 \% \mathrm{MoO}_{3}$ & $10 \% \mathrm{MoO}_{3}$ & $3.3 \% \mathrm{CoO} / 14.7 \% \mathrm{MoO}_{3}$ \\
Surface Area $\left(\mathbf{m}^{2} / \mathbf{g}\right)$ & 154 & 167 & 323 \\
Average Pore Diameter $(\AA)$ & 123 & 122 & 58 \\
Pore Distribution & bimodal & bimodal & bimodal \\
Size, inches diam & $1 / 16$ & $1 / 16$ & $1 / 16$ \\
\hline
\end{tabular}

\subsubsection{Process: Exxon Donor Solvent (EDS)}

Description: The Exxon donor solvent (EDS) process was developed by Exxon Research and Engineering $(E R \& E)$ and is a thermal liquefaction process where the donor solvent is catalytically hydrotreated in a fixed bed reactor external to the liquefaction zone [17-19]. Typical liquefaction reactor conditions are $840^{\circ} \mathrm{F}$ and 2,000-3,000 psia with 45 minutes residence time.

- Background:

Process developed by Exxon Research and Engineering

- Two pilot plants (75 lb/day) and a third (1 ton/day) at Baytown Research

- Development Division in Houston, TX set the design scale-up basis

- Larger EDS process (250 ton/day) built and operated at Baytown, TX

- Operator: Exxon

- Cost: \$341 MM

- Participants: US Department of Energy (DOE), Exxon, Electric Power Research Institute (EPRI), Japan Coal Liquefaction Development Company, Phillips Coal Company, Anaconda Minerals Company, Ruhrkohle AG, ENI (Italian National Oil Company) 
- Process Schematic:

Figure 5. Exxon donor solvent process.

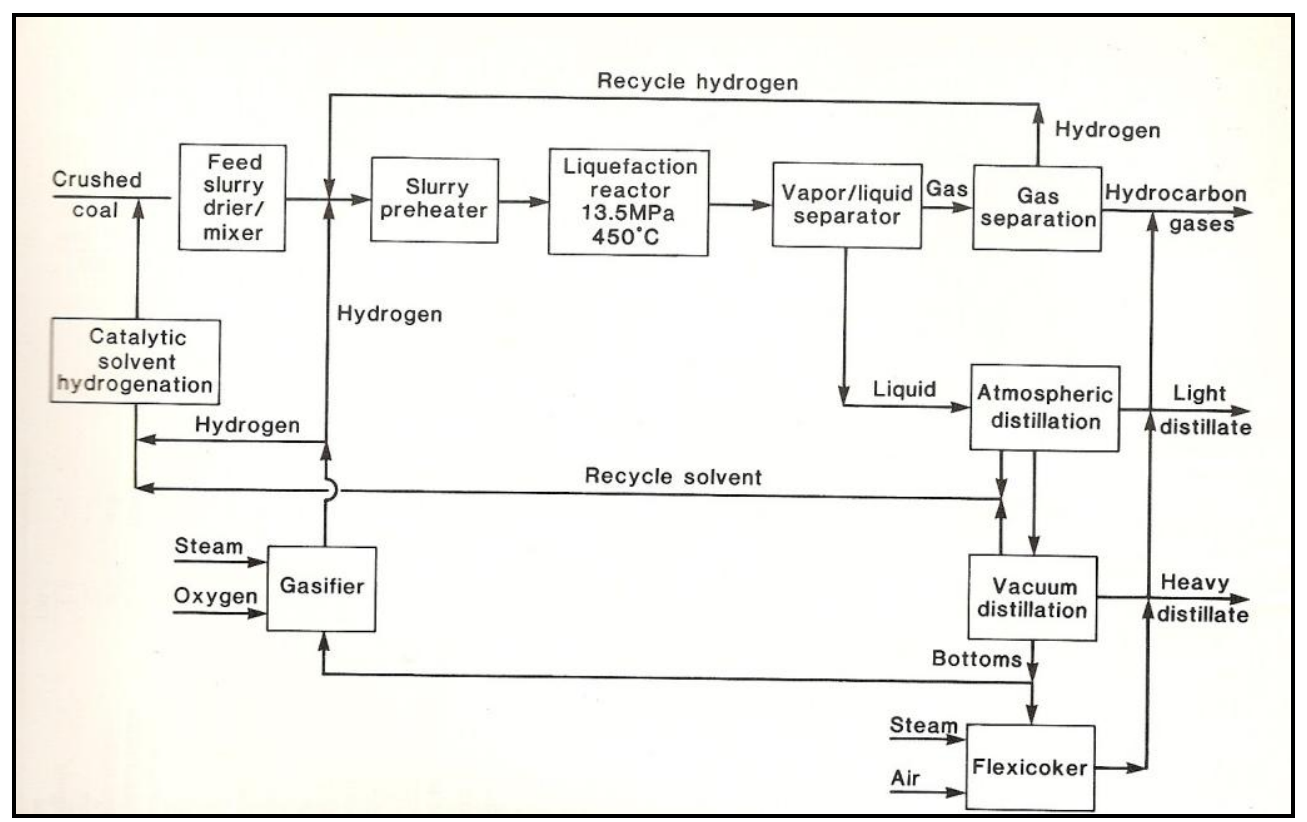

- Process Yields:

Table 10. Product yields of EDS process (2,500 psig, $\left.840{ }^{\circ} \mathrm{F}\right)$.

\begin{tabular}{lccc}
\hline & $\begin{array}{c}\text { Illinois No. 6 } \\
\text { bituminous } \\
\text { (Monterey) }\end{array}$ & $\begin{array}{c}\text { Wyoming } \\
\text { subbituminous } \\
\text { (Wyodak) }\end{array}$ & $\begin{array}{c}\text { Texas } \\
\text { lignite } \\
\text { (Big Brown) }\end{array}$ \\
\hline Residence time (min) & 40 & 60 & $\mathbf{2 5 - 4 0}$ \\
Yields (wt\% maf coal) & & & \\
$\mathrm{H}_{2}$ & -4.3 & -4.6 & $\mathbf{- 3 . 9}$ \\
$\mathrm{H}_{2} \mathrm{O}+\mathrm{CO}_{x}$ & 12.2 & 22.3 & $\mathbf{2 1 . 7}$ \\
$\mathrm{H}_{2} \mathrm{~S}+\mathrm{NH}_{3}$ & 4.2 & 0.9 & $\mathbf{1 . 7}$ \\
$\mathrm{C}_{1}-\mathrm{C}_{3}$ gas & 7.3 & 9.3 & $\mathbf{9 . 1}$ \\
$\mathrm{C}_{4}-1000{ }^{\circ} \mathrm{F}$ liquid & 38.8 & 33.3 & $\mathbf{3 3 . 3}$ \\
$1000{ }^{\circ} \mathrm{F}+$ bottoms & 41.8 & 38.8 & $\mathbf{3 8 . 1}$ \\
\hline
\end{tabular}

\subsubsection{Process: Solvent Refined Coal, SRC}

Description: The Solvent Refined Coal liquefaction process referred to as SRC-II is a thermal liquefaction process; it is an outgrowth of an earlier Solvent Refined Coal process tested by Gulf Oil in the 1960s [20-24]. The earlier process, known as SRC-I, was aimed at boiler fuel production of an ashless low-sulfur solid fuel. In contrast, the SRC-II is geared to the production of synthetic liquid fuels. Typical reactor conditions are $870{ }^{\circ} \mathrm{F}, 1,500-2,500 \mathrm{psig}$, and $15-45$ minutes with no catalyst. 
- Background:

Two major pilot plants:

- 50 TPD at Fort Lewis, Washington under Gulf Oil and DOE

- 6 TPD at Wilsonville, Alabama originally built by Catalytic, Inc. under sponsorship of Southern Company Services, Inc.

- Process Schematic:

Figure 6. SRC process.

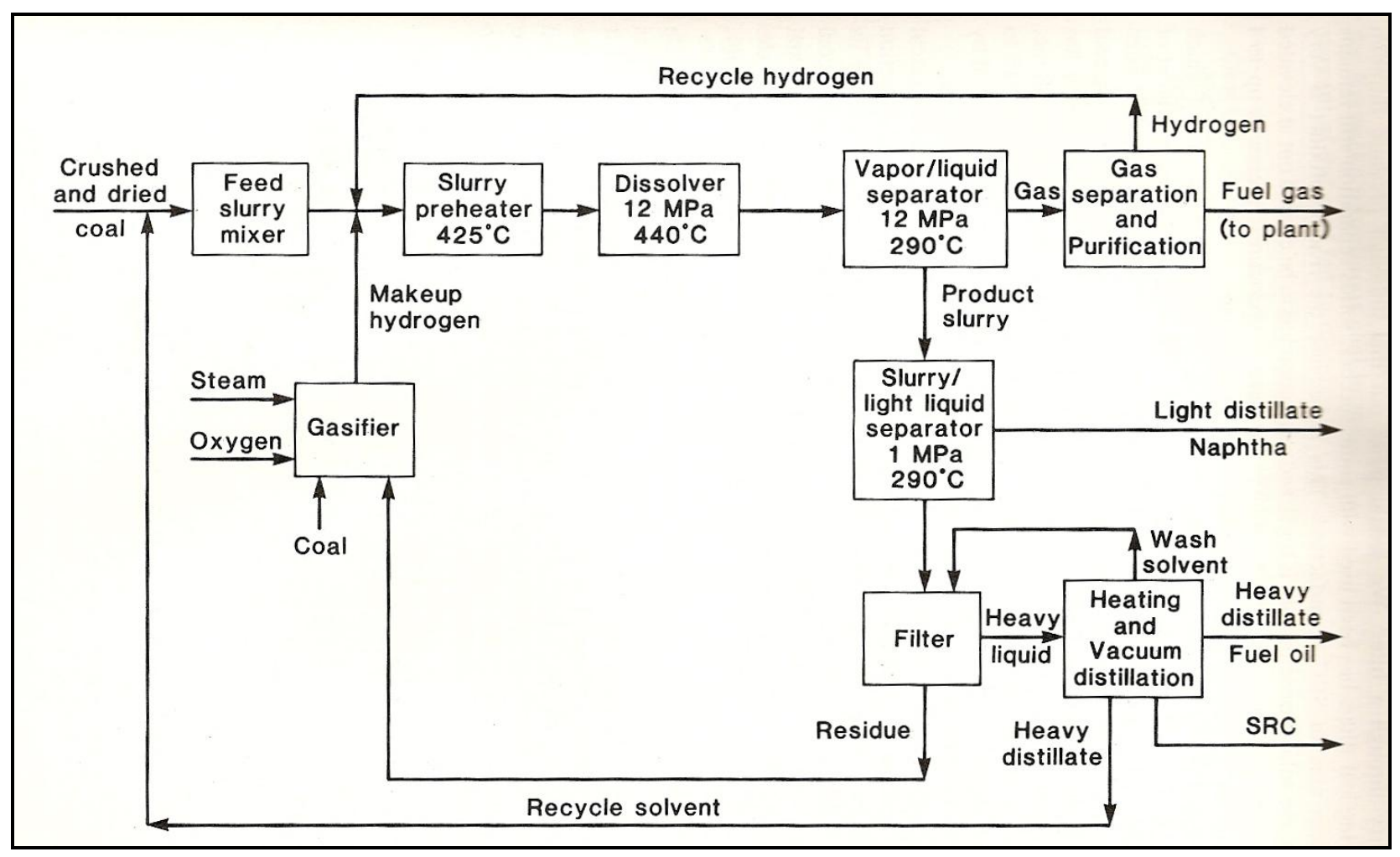

Table 11. Process yields for SRC II process for Kentucky Bituminous Coal.

\begin{tabular}{ll}
\hline & $\mathrm{Wt} \%$ \\
\hline Consumed & \\
\hline Hydrogen & 4.8 \\
Total & 4.8 \\
\hline Produced & \\
\hline Fuel Gas $\left(\mathrm{C}_{1}-\mathrm{C}_{4}\right)$ & 17.6 \\
Naphtha $\left(\mathrm{C}_{5}-350{ }^{\circ} \mathrm{F}\right)$ & 13.0 \\
Fuel Oil $\left(350-850{ }^{\circ} \mathrm{F}\right)$ & 25.8 \\
Solvent Refined Coal & 26.5 \\
Unconverted Carbon & 6.3 \\
Hydrogen Sulfide & 2.5 \\
Carbon Oxides & 2.0 \\
Water & 5.7 \\
Ammonia & 0.6 \\
Total & 100.0 \\
\hline
\end{tabular}




\subsubsection{Process: Two Stage Coal Liquefaction}

Description: Compared to SRC-I \& SRC II, two-stage liquefaction tightly couples the dissolver and catalytic hydrotreater so that the time between the two stages is minimized. Ash removal occurs after the second catalytic stage rather than interstage deashing. This accomplishes higher liquid yields with less hydrogen consumption with two stages operating at different temperature. Second stage always has catalyst in it but the first stage can be either catalytic or thermal. Typical reactor conditions are 2,500 psig, 2/1 Slurry Oil/Coal, 45-70 lbs/hr- $\mathrm{ft}^{3}$ cat (each stage), 650-775 ${ }^{\circ} \mathrm{F}$ first stage and $810-825^{\circ} \mathrm{F}$ second stage [25].

- Background:

- Original concept introduced by Chevron Research in late 70s (US)

- Pilot plant tests by HRI, Inc. in mid 80's with exceptional success noted by high distillate and low residuum yields.

- Wilsonville pilot plant operating as SRC was modified to tightly couple the 1st stage dissolver with 2nd stage H-Oil hydrotreater in 1986-1987 and called RITSL (Reconfigured Integrated Two-Stage Liquefaction) operating mode.

- Two stage process under some debate with high/low and low/high temperature staging not showing yields too different. HRI favored a low/high staging while Amoco prefered high/low to favor aromatic saturation in 2nd stage.

- 6 TPD at Wilsonville, Alabama originally built by Catalytic, Inc. under sponsorship of Southern Company Services, Inc eventually set up as:

\section{Sponsors}

US Department of Energy

Electric Power Research Institute

Amoco Corporation

Southern Company Services, Inc.

\section{Participants}

Catalytic, Inc.

Kerr-McGee Corporation

Hydrocarbon Research, Inc.

Integration of $\mathrm{H}$-Oil hydrotreater into process employed at Wilsonville so that some of recycle slurry oil came from catalytic hydrotreater; it led to the process being called two-stage liquefaction with the standard integrated mode (ITSL) and double integrated mode (DITSL).

Critical Solvent Deashing (CSD) by Kerr-McGee eliminated filters and allowed recycle of heavy residue as major component of slurry oil. 
- Process Schematic for Two Stage Liquefaction (ITSL at Wilsonville, AL):

Figure 7. Two stage liquefaction.

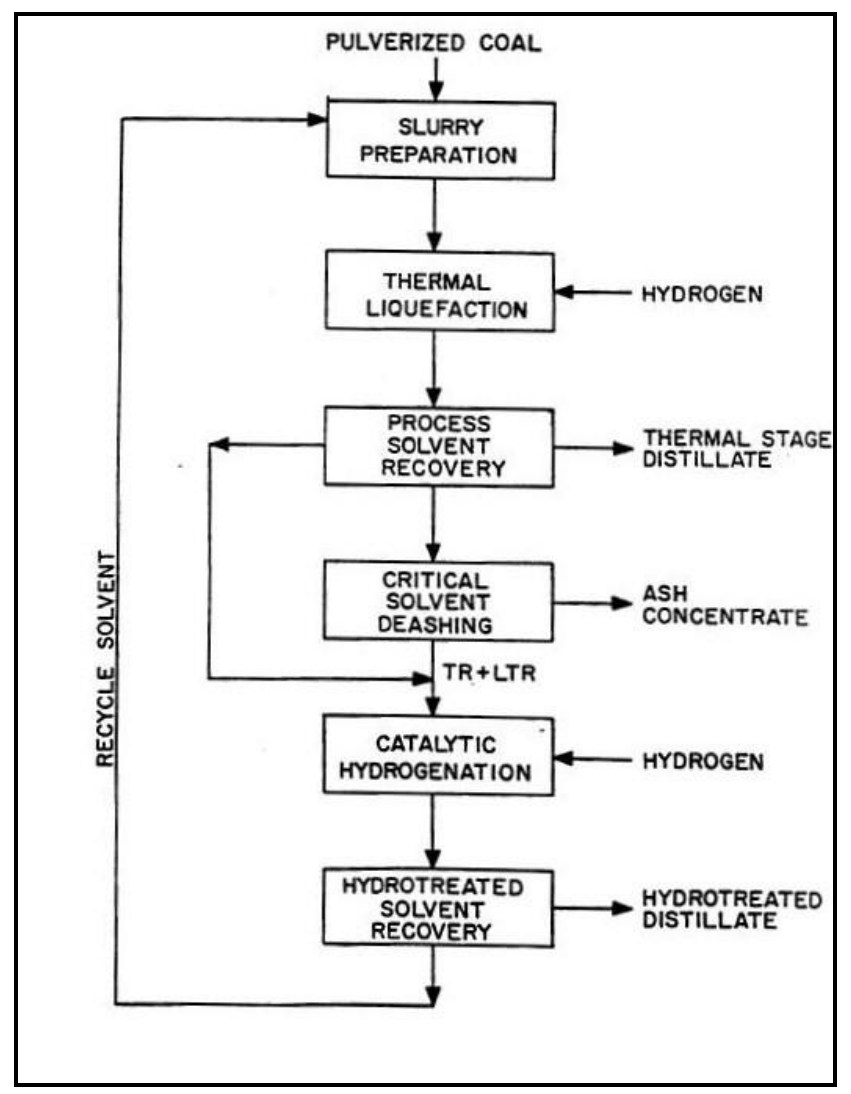

Table 12. Process yields for Wilsonville Pilot Plant- two stage Mode- Illinois Bituminous Coal.

\begin{tabular}{|c|c|c|c|c|c|c|}
\hline \multirow[b]{2}{*}{ Run No. } & \multicolumn{2}{|c|}{ ITSL } & \multicolumn{4}{|c|}{ DITSL } \\
\hline & $246 \mathrm{~F}$ & $246 \mathrm{G}$ & $246 \mathrm{~A}$ & $246 \mathrm{~B}$ & $246 \mathrm{C}$ & 246DE \\
\hline Yield* (\% maf coal) & & & & & & \\
\hline $\mathrm{C}_{1}-\mathrm{C}_{3}$ gas (total gas) & $8(19)$ & $9(19)$ & $7(17)$ & $6(14)$ & $5(13)$ & $9(17)$ \\
\hline Water & 12 & 11 & 12 & 11 & 12 & 12 \\
\hline $\mathrm{C}_{4}+$ distillate & 51 & 53 & 51 & 50 & 49 & 55 \\
\hline Resid & 3 & 1 & -2 & -1 & 0 & -1 \\
\hline Hydrogen consumption & -5.1 & -5.4 & -5.0 & -4.6 & -4.1 & -5.4 \\
\hline $\begin{array}{l}\text { Hydrogen efficiency } \\
\left(\mathrm{lb} \mathrm{C}_{4}+\text { dist } / \mathrm{lb} \mathrm{H}_{2} \text { consumed }\right.\end{array}$ & 10.0 & 9.8 & 10.3 & 11.0 & 12.0 & 10.2 \\
\hline $\begin{array}{l}\text { Distillate selectivity } \\
\left(\mathrm{lb} \mathrm{C}_{1}-\mathrm{C}_{3} / \mathrm{lb} \mathrm{C}_{4}+\text { dist }\right)\end{array}$ & 0.17 & 0.18 & 0.14 & 0.12 & 0.10 & 0.15 \\
\hline $\begin{array}{l}\text { Energy content of feed coal } \\
\text { rejected to ash concentrate. }(\%)\end{array}$ & $22-24$ & $22-24$ & $26-29$ & $29-32$ & $30-35$ & $21-24$ \\
\hline
\end{tabular}


Table 13. Catalytic two-stage liquefaction process (HRI tests). Wyodak coal yields and process performance. Run 227-22.

\begin{tabular}{|c|c|c|}
\hline & $\begin{array}{l}\text { Process Yields Range } \\
\text { (lb/lb mf coal) }\end{array}$ & $\begin{array}{l}\text { Representative } \\
\text { Yield (lb/lb mf coal) }\end{array}$ \\
\hline \multicolumn{3}{|l|}{ Yield, w \% m.a.f. coal } \\
\hline $\mathrm{C}_{1}-\mathrm{C}_{3}$ & $5-9$ & 8.1 \\
\hline $\mathrm{C}_{4}-390^{\circ} \mathrm{F}$ & $17-27$ & 25.0 \\
\hline $390-650^{\circ} \mathrm{F}$ & $30-47$ & 36.5 \\
\hline $650-975^{\circ} \mathrm{F}$ & $0-11$ & 4.2 \\
\hline $975^{\circ} \mathrm{F}^{+}$Resid & $0-5$ & 1.9 \\
\hline Unconverted Coal & $7-21$ & 10.7 \\
\hline $\mathrm{H}_{2} \mathrm{O}, \mathrm{CO}, \mathrm{CO}_{2}$ & $17-23$ & 20.0 \\
\hline $\mathrm{H}_{2} \mathrm{~S}, \mathrm{NH}_{3}$ & $1.4-1.8$ & 1.6 \\
\hline $\begin{array}{l}\text { Hydrogen } \\
\text { Consumption }\end{array}$ & $6.3-8.1$ & 8.1 \\
\hline $\mathrm{C}_{4}-975^{\circ} \mathrm{F}$ Liquid & $54-68$ & 65.7 \\
\hline \multicolumn{3}{|l|}{ Process performance } \\
\hline Coal Conversion & $83-92$ & 89.3 \\
\hline $975^{\circ} \mathrm{F}^{+}$Conversion & $74-90$ & 87.4 \\
\hline Hydrogen Efficiency & $8-9$ & 8.2 \\
\hline
\end{tabular}

Table 14. RITSL yield structures (thermal/catalytic) (Wilsonville pilot plant). Illinois Bituminous Coal.

\begin{tabular}{|l|c|c|c|}
\hline Run No. & 247C-II & 247D & 247E** \\
\hline Yield* (\%maf coal) & & & \\
\hline $\mathrm{C}_{1}-\mathrm{C}_{3}$ gas (total gas) & $7(12)$ & $6(12)$ & $5(11)$ \\
\hline Water & 10 & 9 & 11 \\
\hline $\mathrm{C}_{4+}$ distillate & 60 & 62 & 61 \\
\hline Resid & 5 & 3 & 3 \\
\hline Hydrogen consumption & -6.1 & -6.1 & -6.3 \\
\hline $\begin{array}{l}\text { Hydrogen efficiency } \\
\text { (lb } \mathrm{C}_{4+} \text { dist/lb } \mathrm{H}_{2} \text { consumed) }\end{array}$ & 9.8 & 10.2 & 9.7 \\
\hline $\begin{array}{l}\text { Distillate selectivity } \\
\text { (lb } \mathrm{C}_{1}-\mathrm{C}_{3} / \mathrm{lb} \mathrm{C}_{4+} \text { dist) }\end{array}$ & 0.11 & 0.10 & 0.09 \\
\hline $\begin{array}{l}\text { Energy content of feed coal } \\
\text { rejected to ash conc. }(\%)\end{array}$ & 22 & 22 & 22 \\
\hline
\end{tabular}

* elementally balanced yield structures

** catalytic stage feed sensitivity studies 


\section{Conclusions}

Direct coal liquefaction has advanced from its early beginnings in Germany in the 1940s and can now be viewed as a viable option in the synfuel picture when crude oil prices are in the \$70-80 per barrel range. Compared to indirect liquefaction schemes such as coal gasification/Fischer-Tropsch synthesis, this process makes a much different product slate with naphtha being produced instead of diesel fuel. The energy efficiency is much higher but the process is much more difficult to operate due to the abrasive nature of the coal slurry that erodes pressure letdown valve, the need to stay in donor solvent balance to slurry the coal feed with, and the very difficult solids separation from the liquid product. Still, the advantages of primarily a gasoline product and higher energy efficiency give it some very attractive aspects and it will move forward under some situations, most likely in countries like China, which has huge coal resources.

\section{References}

1. China launches first coal-to-liquids project. China Daily, January 6, 2009.

2. Barta. Patrick South Africa has a way to get more oil; Make it from coal. WSJ 2006, CCXLVIII, 1.

3. Robinson, K.K.; Tatterson, D.F. Fischer-Tropsch oil-from-coal promising as a transport fuel. Oil Gas J. 2007, 105, 20-31.

4. Robinson, K.K.; Tatterson, D.F. Economics on Fischer-Tropsch coal-to-liquids method updated. Oil Gas J. 2008, 106, 22-25.

5. Lumpkin, R.E. Recent progress on the direct liquefaction of coal. Science 1988, 239, 873-877.

6. Schlesinger, M.D. Past Trends in Synthetic Fuels R\&D. PETC/TR-80/4, Department of Energy: Pittsburgh, PA, USA, 1980.

7. Fischer, F. The Conversion of Coal Into Oils; Van Nostrand Company: New York, NY, USA, 1925.

8. Given, P.H. Course Notes-Coal Origins and Characteristics; Penn State University: University Park, PA, USA, 1986.

9. Kim, D.; Robinson, K.K.; Gutberlet, L.C.; Bertolacini, R.J. Catalyst development for coal liquefaction. EPRI Contract 408 (1): Report AF-1235; EPRI: Palo Alto, CA, USA, 1979.

10. Fulton, J.W. Testing the catalyst. Chem. Eng. 1986, 93, 71-77.

11. Stohl, F.; Stevens, H. Catalyst deactivation in direct coal liquefaction. a comparative study of wilsonville runs. In Proceedings of the 10th Annual EPRI Contractor's Conference on Clear Liquid and Solid Fuels, Palo Alto, CA, USA, 1985.

12. Kuni, D.; Levenspiel, O. Fluidization Engineering Journal; Wiley \& Sons: Hoboken, NJ, USA, 1969.

13. Levy, R.B.; Cusumano, J.A. New Materials for Coal Liquefaction. Liquid Fuels from Coal; Academic Press: New York, NY, USA, 1977.

14. Autoclave Engineers Bulletin 1200. Autoclave Catalytic Reactor Selection Guide. 1990.

15. Shah, Y.T. Reaction Engineering in Direct Coal Liquefaction; Addison-Wesley: Boston, MA, USA, 1981.

16. Merdinger, M.; Comolli, A. Recent Developments in the Processing of Western Coal in the H-Coal Process. Sixth Annual EPRI Contractor's Conference, Palo Alto, CA, USA, 1982. 
17. Epperly, W.R.; Plumlee, K.W.; Wade, D.T. Exxon donor solvent coal liquefaction process: Development program status VI. Chem. Eng. Prog. 1981, 5, 73-79.

18. Hsia, S.J. Liquefaction of Low Rank Coals with the Exxon Donor Solvent Coal Liquefaction Process. In Proceedings of the 11th Biennial Lignite Symposium, San Antonio, TX, USA, June 1981.

19. Ansell, L.L.; Tauton, J.W.; Trachte, K.L. Bottoms recycle studies in the EDS process development, In Proceedings of the 5th Electric Power Research Institute Contractor's Conference on Coal Liquefaction, Palo Alto, CA, USA, May, 1980.

20. Nalitham, R.V. An experimental evaluation of the residence time distribution in the wilsonville dissolver using radioactive tracers. In Proceedings of the 10th Annual EPRI Contractors' Conference on Coal Liquefaction, Palo Alto, CA, USA, 23-25 April, 1985.

21. Moniz, M.J. Process studies of integrated two-stage coal liquefacton at wilsonville. In Proceedings of the 9th Annual EPRI Contractors' Conf on Coal Liquefaction, Palo Alto, CA, USA, 8-10 May, 1984.

22. Gir, S.; Rhodes, D.E. Recent developments in the integrated two-stage coal liquefaction program at Kerr-McGee corporation. In Proceedings of DOE Direct Coal Liquefaction Contractors' Review Meetings, Palo Alto, CA, USA, November, 1983.

23. Rao, A.K. Recent developments in two-stage coal liquefaction at Wilsonville. In Proceedings of DOE Direct Coal Liquefaction Contractors' Review Meeting, Palo Alto, CA, USA, November 1983.

24. Moniz, M.J.; Nalitham, R.V. An assessment of the impact of delayed deashing and subbituminous coal processing on hydrotreating catalyst performance. In Proceedings of the 10th Annual EPRI Contractors' Conference on Coal Liquefaction, Palo Alto, CA, USA, April, 1985.

25. Comolli, A.G.; MacArthur, J.B.; McCleary J.B. Two-stage catalytic conversion of wyodak coal. In Proceedings of the 10th Annual EPRI Contractor's Conference on Clean Liquid and Solid Fuels, Palo Alto, CA, USA, October, 1985.

(C) 2009 by the authors; licensee Molecular Diversity Preservation International, Basel, Switzerland. This article is an open-access article distributed under the terms and conditions of the Creative Commons Attribution license (http://creativecommons.org/licenses/by/3.0/). 